\title{
Gelişimsel Açıdan Eleştirel Düşünme ve Çocuklarda Eleştirel Düşünmenin Desteklenmesi
}

\author{
Developmentally Critical Thinking and \\ Supporting Critical Thinking in Children
}

\author{
Kevser TOZDUMAN YARALI ${ }^{1}$
}

• Geliş Tarihi: 06.03.2019 • Kabul Tarihi: 04.08.2019 • Çevrimiçi Yayın Tarihi: 04.08.2019

\section{$\ddot{\mathbf{O z}}$}

Üst düzey düşünme becerilerinden biri olan eleştirel düşünme bebeklikten yetişkinliğe uzanan bir süreç içerisinde gelişmektedir. Ancak bunun için eleştirel düşünme becerisinin gelişimini destekleyecek bir çevreye ihtiyaç vardır. Çocukların, hızla ulaşılan bilginin hangisinin güvenilir olup olmadığını ayırt etmeleri için bilgiyi eleştirel bir yolla değerlendirme becerisine sahip olmaları gerekmektedir. Bu makalede eleştirel düşünme gelişimsel bakış açısıyla incelenmiş, konu ile bağlantılı araştırmalardan yola çıkılarak eleştirel düşünmenin gelişimsel seyri anlaşılmaya çalışılmıştır. Ayrıca çocuklarda eleştirel düşünme becerisinin desteklenmesi için önerilere yer verilmiştir.

Anahtar sözcükler: eleştirel düşünme, eleştirel düşünmenin gelişimi, eleştirel düşünmenin desteklenmesi, üstbiliş.

\section{Atıf:}

Tozduman Yaral1, K. (2020). Gelişimsel açıdan eleştirel düşünme ve çocuklarda eleştirel düşünmenin desteklenmesi. Pamukkale Üniversitesi Eğitim Fakültesi Dergisi, 48, 454-479. doi: 10.9779/pauefd.536546.

\footnotetext{
${ }^{1}$ Dr. Öğr. Üyesi, Kırklareli Üniversitesi, kevseryarali@klu.edu.tr
} 


\begin{abstract}
Being among higher-order thinking skills; critical thinking develops in a process extending from infancy to adulthood. However, this requires an environment to support the development of critical thinking skills. In order for children to discern which rapidly-reached information is reliable, they need to have a skill of assessing the information in a critical way. In this paper, critical thinking was examined from a developmental point of view and it was tried to understand the developmental course of critical thinking on the basis of relevant studies. In addition, suggestions were made to support critical thinking skill in children.
\end{abstract}

Keywords: critical thinking, development of critical thinking, supporting critical thinking, metacognition.

\title{
Cited:
}

Tozduman Yaral1, K. (2020). Developmentally critical thinking and supporting critical thinking in children . Pamukkale Üniversitesi Ë̆itim Fakültesi Dergisi, 48, 454-479. doi: 10.9779/pauefd.536546. 


\section{Giriş}

Eleştirel düşünmenin tarihi ünlü Yunan filozofu Sokrates'e (M.Ö 470 - M.Ö 399) uzanır. Sokrates, günümüzde Sokrates yöntemi olarak bilinen sorgulama tekniğini geliştirmiştir. Soru sorma üzerine kurulu olan bu teknik, doğruluğundan emin olunsa bile bir bilginin sorgulandığında mantıksız olabileceğini ortaya çıkarmayı amaçlar (Başarer, 2017). Ünlü eğitim felsefecisi John Dewey'in görüşleri de eleştirel düşünmeyi etkilemiştir. Dewey (1933) düşüncenin niteliğini bireyin çevresiyle olan deneyimiyle ilişkilendirmiştir. Deneyimleyerek öğrenmenin önemini vurgulayan Dewey, öğrenirken uygulamanın eleştirel düşünmeyi teşvik eden sorgulayıcı bir süreç olduğunu belirtmiştir (Dewey, 1933). Eleştirel düşünme kavramının uzun geçmişine bakıldığında hem felsefe hem eğitim alanına konu olduğundan farklı araştırmacılar tarafından çeşitli şekillerde tanımlandığı görülmektedir (Ennis, 1985; Facione, 1984; Lewis \& Smith, 1993; Paul, vd., 1989; Watson Glaser, 1980). Çoğu zaman eleştirel düşünme problem çözme, yaratıcı düşünme gibi diğer düşünme becerilerinin yerine kullanılmıştır (Daniel \& Auriac, 2011). Örneğin, Ennis (1985) problem çözme becerisine atıfta bulunarak eleştirel düşünmeyi bireyin hem inancına hem de davranışına karar vermeye etki eden yansıtıcı düşünme türü olarak nitelemiştir. Facione (1984) ise eleştirel düşünmeyi iddiaların/delillerin geliştirilmesi ve değerlendirilmesi” olarak açıklamıştır. Eleştirel düşünmenin tanımı konusundaki bu karışıklık (1988-1989) yıllarında eleştirel düşünme konusunda önemli bir araştırmacı olan Peter Facione önderliğinde gerçekleştirilen Delphi Projesi ile giderilmiştir. Felsefe, eğitim, sosyal bilimler ve fizik bilimi alanındaki uzmanların görüşleriyle eleştirel düşünmenin hangi becerileri kapsadığ konusuna açıklık getirilmiştir. Buna göre eleştirel düşünmenin yorumlama, analiz, değerlendirme, çıkarım, açıklama ve öz düzenleme bilişsel becerilerini kapsadı̆̆ı belirlenmiştir (Facione, 1990).

Eleştirel düşünme her bireyin sahip olduğu bir beceri değildir ancak desteklendiğinde geliştirilebilen bir beceridir (Demirel, 1999). Eleştirel düşünmenin gelişimi erken çocukluktan ergenlik ve yetişkinliğe kadar gelişen birtakım öncü beceri üzerine kuruludur. Dolayısıyla eleştirel düşünmenin gelişmesini etkileyen pek çok faktör vardır (Ormrod, 2018). Sosyal ve duygusal gelişim, deneyim, oyun, iletişim, çevrenin zihinsel temsilleri, soyut düşünme becerileri gibi öncü beceriler çocuklardaki eleştirel düşünme becerilerinin temelini oluşturmaktadır (Murphy, vd., 2014). Tüm bu faktörlerden yola çıkarak eleştirel düşünmenin bebeklikten ergenliğe uzanan süreçteki seyrini gelişimsel olarak anlamak bütüncül bir bakış açısı sunacaktır. $\mathrm{Bu}$ çalışmada da konuyla ilgili araştırmalardan yararlanarak yaşanan gelişimsel değişimler yoluyla eleştirel düşünme becerisinin nasıl ortaya çıktığına bütüncül bir bakış açısı sağlamak amaçlanmıştır. Ayrıca çocuklarda eleştirel düşünme becerisinin desteklenmesi için önerilere yer verilmiştir.

\section{Üst Düzey Bir Beceri Olarak Eleştirel Düşünme: Teorik Çerçeve}

Düşünme becerileri, bireyi aktif kılan, bireyin öğrenmesinde sorumluluk alma duygusunu geliştiren, öğrenmenin kalıcılığını sağlayan, araştırma yol ve yöntemlerini kazandıran temel becerilerdir (Dağlığlu ve Çakır, 2010). Temel düzey düşünme dünya hakkında bilgi edinme ile ilgiliyken üst bilişsel beceriler olarak adlandırılan üst düzey düşünme/ikinci düzey düşünme kişinin kendisinin ya da başkasının bilgisi hakkında bilmeyi içerir (Kuhn, 1999). Bir kişi, yeni bir bilgi ile var olan bilgisini alıp yeniden düzenlediğinde ve bu bilgiyi bir amaca ulaşmak için 
ya da şaşırtıcı durumlarda olası cevapları bulmak için genişlettiğinde üst düzey düşünme oluşur. Üst düzey düşünme yoluyla neye inanacağına ve ne yapacağına karar vermek; yeni bir fikir, yeni bir nesne veya sanatsal bir ifade oluşturmak; tahmin yürütmek ve rutin olmayan bir problemi çözmek gibi amaçlara ulaşılır. Üst düzey düşünmede, yeni bir şey üretme çabası olmadan sunulan bilginin zihne yerleştirilmesi olan temel düzey düşünmeden farklı olarak, zihindeki bilginin anlamlandırılıp yapılandırılması gerekir (Lewis \& Smith, 1993).

Eleştirel düşünme üst düzey düşünme becerilerinden biridir. Eleştirel düşünme en genel ifade ile iddiaların değerlendirilmesidir (Olson \& Astington. 1993), "düşünme hakkında düşünmedir" (Paul, 1990). Bireyin kararlarını, inançlarını ve davranışlarını yönlendirmesinde geçerli ve güvenilir bilgi arayışıdır (Galinsky, 2010). Eleştirel düşünmenin konunun uzmanları tarafindan farklı şekillerde tanımlandığı görülmektedir. İlgili literatür incelendiğinde eleştirel düşünmenin genel olarak bilişsel ve duyuşsal boyutu yönüyle ele alındığı görülmektedir. Bilişsel boyut bireyin eleştirel düşünmesi için sahip olması gereken birtakım becerileri içerir. Duyuşsal boyut ise bireyin sahip olduğu bu becerileri kullanma eğilimini ifade eder. Uygun anlam çıkarmayı, iddiaları, tartışmaları ve nedenleri değerlendirmeyi kapsayan beceriler bilişsel boyutu yansıtırken; eleştirel düşünme becerilerini uygulama eğilimini ifade eden mizaç, davranışlar, alışkanlıklar ve kişisel özellikler eleştirel düşünmenin duyuşsal boyutunu ele almaktadır. Burada belirtilmesi gereken, her iki boyutun da birbiri için gereklilik oluşturmasıdır. Çünkü birey eleştirel düşünme için gerekli olan bilişsel becerilere sahip olabilir, ancak bunları uygulayacak motivasyonu yoksa başarılı olamayabilir. Yine benzer şekilde eleştirel düşünme için gereken duyuşsal eğilime sahip olup, çıkarım yapma, değerlendirme gibi becerilerden yoksunsa eleştirel düşünme konusunda yine başarıya ulaşamaz. Eleştirel düşünmenin bu iki temel boyutu açısından; örneğin, Watson Glaser (1980) eleştirel düşünme becerisine ait beş bilişsel alt beceri boyutu belirlemiş, bunları; tümdengelim, varsayımların farkına varma, çıkarım, yorumlama ve varsayımların değerlendirilmesi olarak sınıflandırmıştır. Facione (1990) gerçekleştirdiği Delphi projesinde eleştirel düşünmenin bilişsel alt boyutlarını altı başlıkta sınıflandırmıştır. Bunlar; yorumlama, açıklama, değerlendirme, çıkarım, analiz ve öz düzenlemedir (Tablo 1).

Tablo 1. Eleştirel düşünme becerileri (Facione, 1990: s. 8-12)

\begin{tabular}{ll}
\hline \multirow{2}{*}{ Yorumlama } & $\begin{array}{l}\text { Çeşitli durum, tecrübe, veri, olay yargı vb. kriterlerin anlamını ya da önemini } \\
\text { kavrama ve ifade etme }\end{array}$ \\
\hline Analiz & $\begin{array}{l}\text { Çeşitli durum, tecrübe, sebep vb. kavramlar ve açıklama türleri arasındaki } \\
\text { amaçlanan ve güncel çıkarımsal ilişkileri saptama }\end{array}$ \\
\hline Çıkarım yapma & $\begin{array}{l}\text { Mantıklı sonuçlara ulaşmak için gerekli unsurları saptama; varsayım ve } \\
\text { hipotezler oluşturma }\end{array}$ \\
\hline Değerlendirme & $\begin{array}{l}\text { Çeşitli durum, tecrübe, veri, olay yargı vb. sunumların güvenirliğini ve sunum } \\
\text { türleri arasındaki çıkarımsal ilişkilerin mantıksal gücünü değerlendirme }\end{array}$ \\
\hline Açıklama & $\begin{array}{l}\text { Muhakemenin sonuçlarını belirtme ve muhakemeyi ikna edici argümanlar } \\
\text { tarzında sunma }\end{array}$ \\
\hline Öz düzenleme & $\begin{array}{l}\text { Kişinin kendi çıkarımlarını, analiz ve değerlendirme becerilerini kullanarak } \\
\text { incelemesi }\end{array}$ \\
\hline
\end{tabular}

Paul vd. (1995) eleştirel düşünme becerilerini birçok özelliği içeren makro ve mikro beceriler başlıklarıyla gruplandırmışlardır. Cheung vd. (2002) ise eleştirel düşünmeyi akıl yürütme ve çıkarım yapma olarak sınıflandırmıştır. Bu sınıflandırmalarda bilişsel boyuta 
yapılan vurgu öne çıksa da duyuşsal boyutu ele alan sınıflandırmalar da mevcuttur. Örneğin, Norris ve Ennis (1989) eleştirel düşünmenin duyuşsal boyutuna vurgu yapmak için "eleştirel ruh" terimini kullanır. Eleştirel düşünme eğilimlerini; nedenleri arama, bilgiye ulaşmaya çalışma, alternatifleri arama, açık fikirli olma gibi özelliklerle açıklar. Norris ve Ennis (1989) duyuşsal stratejiler olarak adlandırdığı eğilimleri; bağımsız düşünme, düşüncelerin altında yatan duyguları fark etme, entelektüel bütünlük, sebat ve cesaret geliştirme gibi özelliklerle ifade eder. Facione (1990) eleştirel düşünmenin duyuşsal boyutlarını genel anlamda yaşama yaklaşım (açık fikirlilik, düşünmede esneklik, meraklılık vb.) ve spesifik konular, sorular ya da probleme yaklaşım (bilgiyi araştırırken gayret göstermek, konu üzerinde dikkati odaklamada özenli olma vb.) olarak iki kategoride ele almıştır. McKnown (1997) ise birçok kavramı değerlendirip eleştirel düşünmenin akıl yürütmeyi değerlendirme (bilişsel boyut) ve eleştirel düşünme çabası (duyuşsal boyut) olarak iki bileşeni olduğunu belirtmiş̧ir. Tüm bunlara ek olarak üstbiliş (Kuhn, 1999) ve ideolojik ve ontolojik inançlar başlıklarının (Cheung, vd., 2002) bazı araştırmacılar tarafindan eleştirel düşünmenin bir boyutu olarak ele alındığ görülmektedir. Bilişsel boyut kadar sık kullanılmamakla birlikte üstbiliş boyutu 'kişinin kendi düşünce sürecinin farkında olması ve bu süreci yönetmesi' anlamına gelmektedir. İdeolojik ve ontolojik inançlar boyutu ise bireylerin bilgi ve gerçeği nasıl gördüğüyle yakından ilgili olduğu temeli üzerine kuruludur. Başka bir ifadeyle bireylerin yeni kanıtların toplanmasıyla birlikte uzman anlayışlarının değişeceğine/gelişeceğine inanmaları durumunda yeni bilgilere eleştirel ve analitik gözle bakmaları daha olasıdır. Bilginin mutlak, değişmeyen bir varlık olduğuna inandıklarında ise eleştirel düşünmeyi gerçekleştirme olasıl1kları daha düşüktür (Ormrod, 2018). Bazı bilim adamları (Paul ve Elder, 2002) ideolojik ve ontolojik inançlar boyutunu, kendi temel varsayımlarının, dünya görüşlerinin ve önyargılarının farkında olmak anlamında bilişsel bir beceri olarak görmektedirler. Son olarak belirtmek gerekirse, eleştirel düşünmenin kavramsallaştırılmasında farklı yaklaşımların çeşitliliğine karşın eleştirel düşünen birinin bilişsel beceriler kadar eleştirel bir ruha sahip olması gerektiği konusunda fikir birliği vardır. Dolayısıyla eleştirel düşünmenin öncelikle bilişsel beceri ve duyuşsal eğilim boyutlarından oluştuğu söylenebilir.

Eleştirel düşünme, fikirlerin ya da durumların doğruluğunu/açıklığını değerlendirmek için durumun ya da fikrin tanımlanmasını, farklı görüşlerin analiz edilmesini ve kanıtların değerlendirilmesini gerektirir (Bruning, Schraw ve Ronning, 1995). Tüm bireylerin özellikle de çocukların, hızla ulaşılan bilginin hangisinin güvenilir olup olmadığını ayırt etmeleri için bilgiyi eleştirel bir yolla değerlendirme becerisine sahip olmaları gerekmektedir (Lone, 2017). Eleştirel düşünme; yaratıcı düşünme, problem çözme ve karar verme gibi diğer düşünme becerileri için gerekliliktir (Ennis, 1985; Kurnaz, 2013; Sternberg, 1985). Ayrıca, odaklanma (bilgiyi takip etme), öz denetim (amaçlı davranma), bağlantılar kurma (alternatif çözümler üretme), bakış açısı alma (başkalarının çözümlerden nasıl etkilendiğini anlama) ve iletişim (ifade etme) gibi birtakım becerilere sahip olmayı gerektirir (Galinsky, 2010).

Eleştirel düşünmenin öz düzenleyici yönü kişinin düşünme süreçlerinin farkında olmasını, vardığı yargılar hakkında değerlendirmede bulunup fikirlerini gözden geçirmesini içerir (Facione, 1990). Araştırmacılar bu açıdan eleştirel düşünme ile üstbiliş arasında ilişki kurmuşlardır (Kuhn ,1999; Olson ve Astington, 1993). Bireyin kendi düşünme süreçlerinin farkında olması ve bu süreçleri kontrol edebilmesi anlamında kullanılan (Özsoy, 2008) üstbiliş Kuhn (2000) tarafından ele alınmış, zihin kuramı (temel olarak insanların farklı inanç ve 
düşüncelere sahip olduğunu anlamak) üst bilişin merkezi olarak görülmüştür. Biliş, algglama, anlayış ve hatırlama gerektirirken, üstbiliş, kişinin kendi algılama, anlayış, hatırlama vb. hakkındaki düşüncelerini gerektirmektedir (Altıntaş, 2014). Kuhn (1999) eleştirel düşünmenin gerçekleşebilmesi için üstbilişsel bilgi, üstbilişsel stratejiler ve epistemolojik bilgi olmak üzere üç koşul olduğunu belirtmiştir. Üstbilişsel bilgi, bilginin farkında olmak anlamına gelmektedir. Üstbilişsel stratejiler kişinin performansını geliştirmesi ya da bir hedefe ulaşması amacıyla uyguladığı bilişsel veya davranışsal stratejilerinin kullanımı hakkındaki bilgisinin ifade edilmesidir. Üstbilişsel bilgi için 'ona kadar ileri doğru sayabiliyorum, ancak geri doğru sayamıyorum' ifadesi; üstbilişsel stratejiler için 'Yapbozu köşelerinden yapmaya başlamak daha doğru' ifadesi örnek olarak sunulabilir (Kuhn, 1999; Whitebread, vd., 2004). Epistemolojik bilgi ise, kişinin bilgi ve bilmeye yönelik anlayışını genişletmesi olarak ifade edilebilir. 'Herhangi biri bir şeyi nasıl bilir?' ve 'Kendi bilgim hakkında ne bilirim?' soruları da bu kavrama örnek olarak verilebilir. Bilişsel gelişim araştırmalarında giderek daha merkezi bir yeri olduğu kabul edilen bir yapı olan üstbiliş, kişinin kendi düşüncesinin farkında olma ve düşüncenin yönetimi, ya da "düşünmeyi düşünme" gibi ifadelerle tanımlanır ki bu da Facione'nin eleştirel düşünmenin alt boyutu olarak belirttiği öz düzenleme becerisiyle örtüşür. Bilişsel psikolojide, bu tür bilişsel işlevler çoğunlukla "yürütme kontrolü" başlığı altında incelenir (Dean \& Kuhn, 2003). Her ne kadar literatürleri birbirinden bağımsız ve ayrı olsa da üstbiliş ve zihin kuramı aynı amaca hizmet etmekte ve zihinsel olayları anlamayı içermektedir (Altıntaş, 2014). Genel olarak üstbiliş yaşla birlikte gelişir, ancak üstbiliş becerilerinin kazanılmasında öğretimin etkisinin olgunlaşmanın etkisinden daha fazla olduğu belirtilmektedir (Özsoy, 2008). Vygotsky'nin üst bilişsel teoriye etkisi, diğerlerini kontrol etmekten, kendini kontrol etmeye geçiş açıklamasıyla ortaya çıkmıştır. Vygotsky'e göre, üst zihinsel fonksiyonların temelinde sosyal etkileşim büyük bir rol oynar. $\mathrm{Bu}$ durum, öğrenmenin önemli bir kısmının sosyal ortamlarda deneyimlenmesi yoluyla içselleştirilmesidir (Louca, 2008).

Bilişsel gelişimle ilgili farklı kazanımların (zihin kuramı, yürütücü işlevler vb.) gelişimsel bir çerçevede birleştirilmesi, daha önceki kazanımların daha sonrakiler için hazırlanma yollarının araştırılmasını mümkün kılmaktadır (Kuhn, 2000). Bu perspektiften hareketle bu makalede eleştirel düşünme erken çocukluk, orta çocukluk ve ergenlik dönemlerini içeren gelişimsel bakış açısıyla incelenmiştir. Konu ile bağlantılı araştırmalardan yola çıkılarak eleştirel düşünmenin özellikle bilişsel boyutu açısından gelişimsel seyri anlaşılmaya çalışılmıştır.

\section{Bebeklikten Ergenliğe Eleştirel Düşünme: Eleştirel Düşünme Açısından Yaşanan Gelişimsel Değişimler}

Üst düzey düşünme becerileri için gerekli olan zihinsel kapasite yaşam boyu devam eden süreç içinde gelişir (Piaget, 1952). Eleştirel düşünmenin temelleri de bebeklik döneminde atılmaya başlar ve yaşam süresince geliştirilir (Leon, 2015). Bebekleri düşünceleri hakkında sorgulamak kolay değildir (Miller, 2017), ancak onların davranışları bu konuda tahmin yürütülmesine olanak vermektedir. Bebekler iki yaşına kadar dünyayı duyu ve hareket yoluyla algılar ve anlamlandırırlar. Hareket gelişimindeki ilerlemelerle Piaget'in döngüsel tepkiler adını verdiği bir süreç başlar. Rastlantı sonucu gözleriyle ellerini yakalayan bebek bu önemli keşfi gerçekleştirdikten sonra üç-dört ay civarında kendi vücuduyla gerçekleştirdiği döngüsel tepkileri dört-sekiz ay civarında çevresindeki nesnelerle gerçekleştirir. Vurduğunda devrildiğini 
gördüğü kulelere bir sonraki sefer devirmek için vurur. Piaget, kuramındaki duyu motor dönemdeki 'ikincil şemaların eş güdümlenmesi' olarak ifade ettiği evrede, bebeğin şemalarını karmaşık şekilde birleştirebildiğini belirtir. Sekiz-on iki aylar arasına denk gelen bu evre bebeklerin davranışlarında planlılık ve niyetliliğin ortaya çıktığı zamandır. Bu aşamada bebekler ne istediklerinin farkındadırlar ve hedeflerine ulaşmak için şemalarını birleştirebilirler. (Şema; çevreyle belirli etkileşim sonucunda oluşan bir davranış örüntüsüdür). Araç ile amaç arasında ayrım yapmaya başlayan sekiz aylık bir bebek nesneleri amaca ulaşmada bir araç olarak kullanabilir. Sekiz-on iki ay civarında daha bilinçli davranan bebek daha önceden öğrendiklerini bir sonraki durumda kullanmaya başlar. Sehpanın üzerindeki emziğine ulaşmak istediğinde sehpanın örtüsünü çekebilir. Burada görüldüğü gibi amaç ile araç arasında ayrım yapmak olayların öngörülmesini, yani tahmin yürüterek sonuç çıkarma/çıkarım yapma becerisinin temelini oluşturur. Bir yaşından sonra bebekler yeni durumlar için yeni çözüm yolları üretebilirler. Bir buçuk-iki yaşına gelen bebekler daha çok düşünce içeren icatlarla tepki verebilir, zihinde canlandırma yapma yoluyla problemlere çözüm üretebilirler. Bu aşamaya "düşüncenin başlangıcı" ya da "tasavvurlu düşünce" adı verilir. Bu sürece kadar problemleri deneme-yanılma yoluyla keşfederek çözen bebek artık daha gelişmiş bilişsel kalıplara sahiptir. 18. aya kadar problem çözümünde kullanılan deneme-yanılma yöntemi, bu aydan sonra yerini 'zihinsel temsile' bırakır. Yani bebek artık problemi sembollerle düşünerek çözebilmektedir. Oyuncağı ulaşabileceğinden daha yüksek bir yerde bulunan 20 aylık bir bebek uzanmaya çalışıp oyuncağını alamadığında yakındaki bir sandalyeye çıkıp bunu başarabilir. İki yaşında sembollerin kullanımı ön plana çıkar. Dil, bunun en önemli örneğidir (Avc1, 2007; Berk, 2013; Miller, 2017; Wood, 2003).

Bebeklerin davranışları üzerine yapılan araştırmalar altı aylık bebeklerin bile birçok algıya sahip olduğunu göstermektedir. İnsan algısı da bunlardan biridir: Bebekler insanların davranışlarını rastgele gerçekleşen hareketler olarak görmekten çok, insanların niyetlerine odaklanırlar (Galinsky, 2019). Hamlin, Wynn \& Bloom (2007) bu konuda yaptıklar1 araştırmalarında bebeklerin niyetlerden daha fazlasına dikkat ettiklerini belirlemişlerdir. Araştırmada on aylık bebeklere bir kukla sahnesindeki karakterler izletilmiştir. Sahnede tepeye tırmanmaya çalışan bir daire tekrar tekrar başarısız olmaktadır. Sahneye gelen mavi kare kırmızı daireyi ittire ittire zirveye çıkarır. Kırmızı daire mutluluğunu belli etmek için zıplar. Daha sonra sarı üçgen karakter gelir ve onun aşağı ittirip düşürür. Karakterlerin görevlerinden haberi olmayan bir araştırmacı odaya girer ve bebeğe kare ve üçgenin olduğu tepsiyi uzatır. Araştırmanın sonucunda bebeklerin büyük çoğunlu yardımcı olan olumlu karakteri seçmişlerdir. Karakterlerin görevleri değiştiğinde sonuçlar değişmemiştir. Hatta altı aylık bebeklerde de benzer sonuçlara ulaşılmıştır. Bu araştırmanın sonuçları, bebeklerin zarar veren insanlar yerine yardımcı olan insanları tercih etmeye meyilli olduklarını, bunun da bilgi sağlayıcılar olarak kime güven duyacaklarını etkilediğini göstermektedir.

Bilişsel gelişimle ilgili tüm beceriler (düşünme, karar verme, odaklanma, vb.) doğrudan ya da dolaylı olarak beynin prefrontal korteksi ile ilgilidir. Eleştirel düşünme de beyinde bulunan dört lobdan biri olan 'frontal lob' ile ilişkilidir. Prefrontal korteks ise frontal lobun en önemli bölümlerinden biridir. Çünkü prefrontal korteks; iç ve dış, bilinçli ve bilinç dışı, bellekte depolanmış olan ve diğer tüm kaynaklardan gelen uyaranların düzenlenip, birleştirilip meydana gelecek davranışa karar verilen yerdir. Olasılıklı düşünme, akıl yürütme, yorumlama, tahmin etme, bilgileri düzenleme, strateji üretme ve uygulama, davranışları düzenleme, sonuç çıkarma 
preforantal korteksin gelişmesini gerektirir. Çocuklarda bu becerilerin gelişmesi için beynin bu bölümlerinin gelişmesi gerekir ve bu gelişme dört yaş civarında gerçekleşir (Madi, 2014). Prefrontal korteksin gelişimi ergenliğin sonuna kadar devam eder (Santrock, 2014).

İki-dört yaşları arasındaki çocuklar Piaget'e göre sembolik işlev evresindedirler ve bu evredeki çocuklar o anda orada bulunmayan bir nesneyi zihinsel olarak ifade edebilirler. $\mathrm{Bu}$ evrede dil gelişimi hızlanır. Düşünce ve konuşma benmerkezcidir. Dört-yedi yaşlar arasını kapsayan sezgisel düşünce alt evresinde ise, çocuklar akıl yürütmeye ve sorular sormaya başlarlar. Benmerkezcilikte azalma görülür. Çocuklar fikirlerini düzgün ve uzun cümlelerle ifade edebilirler (Bee \& Boyd, 2009; Santrock, 2014). Çocuklar üç yaş civarında önemli bir bilişsel sıçramayla başkalarının kendinden farklı şeyler bilip hissedebileceğini kavramaya başlarlar ve genellikle çocukların ilk yalanlarına bu dönemde rastlanır. Yalan söylemek çocukların kendilerini başkalarının yerine koyabildiklerini gösterir. Ayrıca çocuğun kendini başkasının yerine koyma durumu kişinin başkalarının düşünce ve inançlarını anlamaya yönelik olan zihin kuramıyla (bir kişinin davranışlarından yola çıkarak onun istek, niyet ve inançlarını çıkarsama/yorumlama becerisi) ilişkilidir. Eleştirel düşünmenin, bireylerin bilgi ve gerçeği nasıl gördüğüyle yakından ilgili olduğu temeli üzerine kurulu olan "epistemolojik ve ontolojik inançlar" boyutu da çocukların empati kurma becerisiyle alakalıdır. Aynı zamandan Galinsky (2010)'nin eleştirel düşünme için önkoşul olarak belirttiği becerilerden biri 'bakış açısı alma'dır ki bu yalan söyleyen bir çocuğun bu beceriyi kazanmaya başladığını gösterir. Bu aşamaya gelen bir çocuk, başkalarının duygu ve düşüncelerini "Bu benim başıma gelseydi ne yapardım?" sorusunu sorarak tahmin edebilir (Szalavitz \& Perry, 2017). Bu kazanımların eleştirel düşünmenin duyuşsal boyutuyla ilgili olarak Halpern (1998)'in esneklik ve Ennis (1985)'in açık fikirlilik özelliklerinin temelini oluşturduğu söylenebilir.

Dört-beş yaşındaki çocuklar üç yaşındakilerden farklı olarak, insanların sahip oldukları inançları yanlış olsa bile bu inançlara göre hareket ettiklerini kavrarlar (Miller, 2017). Bono (1985) düşünme becerilerini kazandırmak için geliştirdiği "CoRT Düşünme Programında” dört seviyeli bir başarı hiyerarşisi belirlemiş; bu hiyerarşinin ikinci seviyesinde başkalarının görüşlerini/inançlarını dikkate alarak bir davranışın ya da seçimin sonuçlarına bakıp alternatifleri arayarak düşünmeyi içeren daha yapısal bir yaklaşımı vurgulamıştır. Başkasının görüşlerini alarak yapılan bu işlemleri CoRT'un araçları olarak nitelendirmiştir. Flavell \& Miller (1998) tarafından yapılan araştırmada, beş yaşındaki çocuğa üzerinde şeker resmi olan bir şeker kutusu gösterilir ve içinde ne olduğunu düşündüğü sorulur. Çocuk "şeker" dedikten sonra kutunun içine baktığında kalem olduğunu görür. Çocuğa, kutunun içine henüz bakmamış bir çocuğun kutunun içinde ne olacağını düşüneceği sorulur ve çocuk keyifle "şeker" yanıtını verir. Bu uygulama üç yaşındaki bir çocukla yapıldığında çocuk birinci soruya "şeker" yanıtını verirken ikinci soruya şaşkın bir şekilde "kalemler" yanıtını verir. Üstelik üç yaşındaki bu çocukla daha sonra konuşulduğunda başlangıçta kutuda kalem olduğunu düşündüğünü belirtir. $\mathrm{Bu}$ sonuç, üç yaşındaki çocukların kendi düşünme süreçlerini yönetme konusundaki yetkinliklerinin henüz yeterli olmadığını göstermektedir.

Üç yaşına kadar, çocuklar kendileri ve diğerleri hakkında bilgi sahibi olarak bazı farkındalıklar edinirler. Bir nesne hakkında düşünmeyi onu algılamaktan ayırırlar ve düşünmek ve bilmek gibi fiilleri kullanarak kendi bilgi durumlarına başvurmaya başlarlar (Flavell, 1999). Dört yaşındayken, başkalarının davranışlarının inanç ve arzular tarafından yönlendirildiğini ve 
bu tür inançların kendileri ile uyuşmayabileceğini ve yanlış olabileceğini anlarlar. İnsan bilgisinin dayandığı üretken kaynaklarla iddialar arasında bağlantı kurduğundan yanlış inanç anlayışı (zihin kuramı) gelişimsel bir dönüm noktasıdır. Okul öncesi yıllar aynı zamanda birinin iddiaların ne olduğunu, yani bir kişinin bilgi kaynaklarının farkında olduğunu nasıl bildiği konusunda hızla gelişen bir farkındalık dönemidir. Bu metabilişsel kazanımlar üst düzey düşünmenin temelini oluşturur. Bilgiyi insan bilgisinin ürünü olarak anlamak, epistemolojik düşüncenin geliştirilmesinde kritik bir ilk adımdır; bu, şeylerin nasıl bilindiğini ve giderek daha üst düzey düşünmede etkili olarak nasıl tanındığına dair kesin bir teori oluşturmak anlamında metabilişseldir (Kuhn, 2000). Lutz \& Keil (2002) 4 yaşından küçük çocukların bir doktorun biyoloji hakkında ve bir oto tamircisinin mekanik cihazların işleyişi hakkında daha fazla bilgi sahibi olabileceğini düşündüklerini ortaya koymuşlardır.

Basit açıdan okul öncesi çocukların bile düşünmeyi düşünebildikleri söylenebilir. Üç ila beş yaşları arasında, çocuklar iddiaların birinin inancının ifadesi olduğu görüşünü edinir (Olson \& Astington, 1993). Bu, eleştirel düşünmenin 'bilişsel' ve 'ideolojik ve ontolojik inançlar boyutu' için temel oluşturur (Ormrod, 2018; Paul ve Elder, 2002) ve üst düzey düşünmenin gelişiminde kritik bir işarettir. Bu içgörüyü elde ettikleri zaman, çocuklar zihinsel durumları temsil etme yeteneğini geliştirmiş olurlar; örneğin, bir köpeği düşünmeyi aslında birini algılamaktan ayırırlar (Estes, Wellman \& Woolley, 1989). Ayrıca, arzu ve niyet gibi zihinsel durum kavramlarını kendilerinin ve başkalarının davranışlarını açıklamada bir araç olarak kullanmaya başlarlar (Wellman \& Gelman, 1998). Hoicka vd. (2017) yaptıkları çalışmada okul öncesi çocukların güveni istikrarlı görmediklerini (birine olan güvenlerinin niyetlere göre değiştiğini), aksine insanların değişen niyetlerinin bir işlevi olarak gördüklerini bulmuşlardır. Bununla birlikte, küçük çocuklara ağaca tırmanan ve ağaçtan düşüp dizini tutan bir çocuğun resmi gösterilip "Bu çocuğun düştügünü nereden biliyorsun?" sorusu sorulduğunda büyük çoğunluğunun "Dikkatle tutunmadığı için" (dizini tuttuğu için yerine) cevabını verdikleri görülür (Kuhn, 1999). Ayrıca, evlerinde diş fırçasının bulunduğu yeri düşünmeleri ve daha sonra ne hakkında düşündüklerinden bahsetmeleri istendiğinde 5 yaşındaki çocukların banyodan veya diş firçalarından bahsetmekte zorlandıkları görülmüştür (Flavell, Green, \& Flavell, 1995). $\mathrm{Bu}$ durum çocuklarda yaşla birlikte gelişen ve eleştirel düşünme becerilerinin kazanılmasında da bir gereklilik olan üstbiliş becerilerinin -kişinini kendi düşüncesinin farkında olma ya da düşünmeyi düşünme- hala gelişmekte olduğunu göstermektedir (Dean \& Kuhn, 2003). Ayrıca, beş yaşındaki çocukların ne düşündüklerini hatırlamakta zorlanmaları açısından bakıldığında “düşünmeyi düşünme” kavramı, Paul, vd. (1995)'nin eleştirel düşünme için gerekli bir özellik olarak belirttiği mikro beceriler arasında yer almaktadır.

Okul öncesi yıllarda çocuklar aldatma olasılığını anlamaya başlarlar. Görünüş ve gerçeğin bazen farklılaştığını ve insanların yanlış inançlara sahip olabileceğini öğrenirler (Moses \& Baldwin, 2005). Çocuklar 3 yaşına geldiklerinde, sözlü ifadelerin aldatıcı bir konuşmacının gerçek inançlarını yansıtmayabileceğini anlarlar (Lee \& Cameron, 2000). Küçük çocuklar, insanların bildiklerini her zaman doğru bir şekilde iletmediklerini anlama kapasitesine sahip olsalar da, çoğu zaman yetişkinlerin çarpık bilgi sağlamak için yaptığı çıkarım türlerini yapmayı başaramazlar. Mills \& Keil (2005) anaokulu, ikinci sınıf ve dördüncü sinıf çocuklarından, bir konuşmacının belirsiz bir olayla ilgili iddialarını değerlendirmelerini istediği bir araştırma yürütmüştür. Senaryolardan biri, kimin kazandığını belli etmediği bir koşma yarışı veya kazandığını ya da rakibinin kazandığını iddia eden bir karakter içermektedir. Çalışma 
sırasında ikinci sınıf ve daha büyük yaştaki çocuklar, konuşmacının kişisel çıkarlarıyla tutarlı olan iddialara daha kuşkuyla yaklaşmışlardır. Bununla birlikte anaokulu çocukları, konuşmacı tarafından belirtilen sonuçları tarif ettiklerinde bu ifadelerin doğru olduğunu varsaymaya yönelik bir önyargı olarak yorumlanan bu iddialardan daha az kuşku duymuşlardır. Bu sonuç, okul öncesi çocukların Paul, vd. (1995)'nin makro bilişsel beceriler olarak ele aldıkları "delil ve iddia edilen gerçeklerin değerlendirilmesi” özelliğinde ve Norris ve Ennis (1989)'in eleştirel düşünme eğilimlerinin bir özelliği olarak belirttikleri "açık fikirli olma" konusunda henüz başarılı olamadıklarını göstermektedir.

Gelişim psikolojisi açısından düşünme hakkında düşünme Piaget'in dönemleri yönüyle somut işlemler dönemiyle ilişkilendirilir (Inhelder \& Piaget, 1958). Piaget'in görüşlerine karşit olarak sonraki araştırmalar düşünme hakkında düşünmenin somut işlemler dönemiyle sınırlandırılacak bir beceri olmadığını ortaya atmıştır (Matthews, 2000; McCall, 2017; Moshman, 1998). Çocukların kendileri için önemli olan bir konu hakkında eleştirel düşünmeyi nası1 üstlendiklerini gösteren araştırmalar mevcuttur. Örneğin McCall (2017) beş yaşındaki çocuklarla yürüttüğü felsefi sorgulama yöntemi (Felsefi Sorgulala Topluluğu -FST-) sırasında çocukların doksan dakikalık diyalog sürecine katılabildiklerini, akıl yürütebildiklerini ve soyut fikirler kullanabildiklerini ortaya koymuştur. Bu açıdan McCall (2017)'un çalışması, firsat verildiğinde ve çocuklara uygun koşullar oluşturulduğunda çocukların beklenenden daha erken bu becerileri kullanabildiklerini göstermektedir. Eleştirel düşünmenin erken çocuklukta görüldügünü savunan araştırmacılar (Davis-Seaver vd., 2003; MacCall, 2017) için Piaget'nin görüşleriyle ilgili sorunlar (erken çocuklukta eleştirel düşünmenin görülemeyeceği), Piaget'in ortaya attığı soyut düşünmenin (formel akıl yürütmenin) eleştirel düşünme ile aynı olduğu düşüncesinden kaynaklanmaktadır. Piaget'e göre soyut düşünme, somut nesnelerle bağımsız sembollerin manipüle edilmesini içerirken, eleştirel düşünme, düşünmenin ne ile yapıldığı ve ne ile yapılması gerektiği ile (iddiaların değerlendirilmesinde kanıt ve gerekçe kullanımı) ilgilidir. Buna göre, küçük bir çocuğun sembolik olarak düşünmeden eleştirel düşünmesi mümkündür. $\mathrm{Bu}$ bakış açısıyla soyut akıl yürütme olmadan da bir çocuk, delilleri inceleme, kanıtlara dayanarak karar verme ve öngörüde bulunma, gerekçeli yargılamalar yapma ve problemleri diyalektik, yaratıcı bir biçimde çözme davranışları gösterebilir (Davis-Seaver vd., 2003). Carlson, Mandell \& Williams (2005)'in yaptığı “Az çoktur” isimli bir araştırmada üç ve dört yaşındaki çocuklara Chris adında bir maymun kukla gösterilir ve Chris'in paylaşmayan yaramaz bir maymun olduğu söylenir. Çocuğa iki tepsi gösterilir; birinde iki ikramlık, diğerinde beş ikramlık vardır. Çocuklara bu oyunda hangi tepsiyi gösterirlerse o ikramlıkların paylaşmayan yaramaz maymuna verileceği, diğer ikramlıkların ise kendilerine kalacağ yaşındaki çocuklar bu oyunda sorun yaşarlarken, dört yaşındaki çocuklar daha az ikramlığın olduğu tepsiyi gösterip çok olan ikramlıkları alabilmişlerdir. Çalışmayı yürüten araştırmacılar, çocukların düşüncelerini ve eylemlerini yönlendirecek daha düşünceli ve yansıtıcı bir bakış açısı elde etmek için onların ani durumlarda geri adım atmayı öğrendiklerini belirtmiştir.

Orta çocukluk dönemi boyunca zihin kuramı olarak adlandırılan çocuğun zihinsel etkinliklere yönelik inançları daha detaylı ve kapsamlı bir noktaya ulaşır. Bu dönem çocukları kendi yaşantılarına yönelik yansıtma yapabildiğinden eleştirel düşünme ve problem çözme gibi düşünme becerilerinde gelişme gözlenir (Berk, 2013; Trawick-Smith, 2018). Orta çocukluk dönemindeki çocuklar, okul öncesi çocuklardan farklı olarak zihni basit bir bilgi deposu olarak görmek yerine onu bilgiyi seçen, dönüştüren aktif bir faktör olarak değerlendirirler (Kuhn, 
2000). Orta çocuklukta bilginin kaynağına yönelik anlayış farklılaşır. Aynı şeyi gören iki insanın bilgi ve deneyim gibi farklılıklarından dolayı düşüncelerinin farklı olacağını anlayabilirler (Eisbach, 2004). Bunun yanında insanların, bilgilerini gözlem yaparak ya da diğer insanlarla konuşmanın dışında, zihinsel çıkarım gibi yollarla geliştirebileceklerini fark ederler (Miller, Hardin \& Montgomery, 2003). Çıkarım yapma becerisinin gelişmesi yanlış inanç bilgisinin de gelişmesini sağlar. Orta çocukluk döneminde bir insanın başka bir insanın düşüncesine yönelik inancını içeren ikinci düzey inanç kavramı gelişir ve çocuklar buna yönelik sorulan sorulara yedi yaşından itibaren doğru cevap verebilirler. Astington, Pelletier \& Homer (2002) tarafından yapılan ikinci düzey bir yanlış inanç testinde çocuklara bir dizi resim gösterilir. Resimlerde Jason adındaki çocuk bir arkadaşından mektup alır. Lisa mektubu okumak istemektedir, ancak Jason buna izin vermez bu nedenle mektubu yastığının altına koyar (buarada Lisa Jason'u kapı arasından izlemektedir). Jason odadan ayrıldığında Lisa mektubu alıp okur. Jason, Lisa'nın yaptığını görür, ancak Lisa Jason'u görmez. Lisa mektubu Jason'un masasına bırakır. Çocuklara ikinci düzey yanlış inanç sorusu olarak "Lisa, Jason'un mektubu nerede arayacağını düşünür? Neden? sorusu sorulur. Çalışmanın sonucunda, yedi yaş civarındaki çocukların bu soruyu doğru yanıtlayabildikleri belirlenmiştir. Çocukların bu düzeye ulaşmaları bir insanın bir kanıya varmasının nedenlerini anlamalarına, başkalarının bakış açılarını kavramalarına yardımcı olmaktadır (Berk, 2013; Miller, 2017). FMRI araştırmaları da buna paralel olarak altı-on bir yaşları arasındaki çocukların bir kişinin düşünceleri hakkında düşünürken aktif olan beyin bölgelerinin zamanla daha ayırt edilebilir düzeye geldiğini göstermektedir. Çocukların yetişkinler gibi prefrontal kortekse ek olarak zihin kuramı sürecinde önemli bir rol oynadığı bilinen sağ temporal lob ve parietal lobu birleştiren beyin alanı aktif duruma gelir (Saxe, vd., 2009).

Orta çocuklukta çocuklar zihinsel stratejiler konusunda daha bilinçli duruma gelirler. Çocuklar zihinsel bir etkinliğin/bilişsel performansın birden fazla faktör tarafından (yaş, motivasyon, görevin zorluk derecesi, stratejilerin kullanımı vb.) etkilendiğinin farkına varırlar ve anlayışlarını daha etkili duruma getirmek için bu faktörleri bir arada kullanmaya başlarlar. Dolayısıyla orta çocuklukta üstbiliş daha karmaşık bir düşünme sistemine evrilmiş olur (Berk, 2013). Dokuz-on bir yaş döneminde çocuklar stratejilerin nasıl ve neden işe yaradığı konusunda farkındalık geliştirirler. Beşinci sınıftaki çocuklar iyi akıl yürütmeyi kötüden ayırabilirler. $\mathrm{Bu}$ çocuklar kendilerine çeşitli örnekler sunulduğunda doğrudan sonuca odaklanmak ve cevap vermek yerine olasılıkları değerlendirerek, verileri bir araya getirerek istenmeyen bir sonuca götüren bir akı1 yürütme şeklini dahi iyi olarak değerlendirebilirler (Amsterlaw, 2006).

Okul öncesi dönem çocukları bile bazen yanlış iddialarda bulunulduğunu anlayabilirken, ilkokul çocukları, kendi çıkarlarına yönelik hizmet etme amaçları açık olan bireylerin ifadelerini sorgulamakta başarısız olabilmektedirler. Bunun bir nedeni bu türden bir bilginin sorgulanmasına yardımcı olacak sosyal deneyimlerin yokluğudur. Gelişimsel olarak her ülkede, büyük çocuklar küçük çocuklardan daha fazla kuşkuculuk sergilemektedirler, ancak kuşkuculuk derecesi Çin'deki altı-yedi yaşındaki çocuklarda ABD'deki 10-11 yaş arası çocuklardan genel olarak daha fazladır. Bu sonuçlar, sosyal tecrübenin çocukların başkalarının iddiaları hakkındaki düşüncelerini büyük ölçüde şekillendirdiğini göstermektedir (Heyman, Fu \& Lee, 2007). Bu durum kültürün eleştirel düşünmenin gelişiminde önemli bir faktör olduğunu gösterir niteliktedir. Bireyin epistemik inancı açısından, otoriteye (büyüklere ya da dini liderlere) doğruyu her zaman bilen bir değer atfeden kültürlerde, bireyin doğrunun sabit bir 
varlık olduğu yönündeki düşüncesi güçlenir. Bunun yanında sürekli grup uyumunun sürdürülmesi gerektiğinin vurgulanması da bireyi eleştirel düşünmenin gerektirdiği düşünce/bakış farklılıklarını dile getirmekten alıkoyabilir ki genel olarak Asya, Kızılderili topluluklarında ve bazı kökten dini gruplarda eleştirel düşünmenin daha az görülmesi bununla açıklanabilir (Ormrod, 2018). DeLoache \& Pickard (2008) dört-sekiz yaş arasındaki çocuklarla bir araştırma yapmıştır. Bu çalışmada araştırmacı çocuklara özel makinem dediği, her şeyi başka şeye dönüştürebildiğini iddia ettiği (nesneleri küçülten, dönüştüren) bir metal makine gösterir. Yanındaki nesneyi alır makinenin içine koyar, çocuktan makinenin üzerindeki yeşil düğmeye basmasını ister, makineden ses gelir ve bir 1şı yanıp söner. Araştırmacı makinenin arkasına gizlenmiş kapaklı bölmedeki küçük el fenerini alır ve çocuğa "Bak! El feneri küçüldü” der. Çocuk bu şekilde dokuz nesnenin dönüşümüne şahit olur. Daha sonra çocuğun ebeveyni odaya girer. Ebeveyn çocuğa "Sence ne oldu? Makine ne yaptı? Değiştirdiğin şeylerin adları neydi? Makine gerçekten onu yaptı mı? Acaba hile mi var? gibi sorular sorar. Araştırmanın sonucunda dört yaşındakilerin $\% 100$ 'ü, beş yaşındakilerin $\% 88$ 'i, altı yaşındakilerin $\% 71$ 'i ve hatta yedi yaşındakilerin \%33'ü bu makinenin sihirli bir şekilde çalıştığına inanmıştır. Daha sonra durum abartılarak 5-8 yaş arasındaki çocuklara, bu makinenin plastik bir kertenkeleyi gerçek bir hayvana dönüştürüp dönüştüremeyeceği sorulmuştur. Araştırmanın sonucunda, beş yaşındaki çocukların \%88'inin altı yaşındaki çocukların \%58'inin, yedi yaşındaki çocukların \%65'inin ve sekiz yaşındaki çocukların \%40'ının gördüklerine ve araştırmacının anlattıklarına inandıkları ortaya çıkmıştır. Galinsky (2010) bu araştırma sonuçları için yaptığı açıklamada, hızla gerçekleşen teknolojilerin birçok zaman yetişkinler için bile imkânsız göründüğünü (gerçekleşmesi imkânsız gibi görünen şeylerin birkaç yıl içinde gerçek olabileceğini gördüklerini), dolayısıyla çocukların da basit şeylere aldanmalarının normal olabileceğini ifade etmiştir. Rosengren, vd. (1994) ise bir sihirbazın hayali bir figürü gerçeğe dönüştürdüğünü iddia ettiği benzer bir araştırmada okul öncesi çocukların genel olarak sihir inancına sahip olduklarını, ancak bu inancın ebeveyn tutumlarından (ebeveyn teşviki) ve çocukların kendilerine özgü inançlarından etkilendiğini belirlemişlerdir. Bu durum eleştirel düşünmede bireyin epistemik inançlarının da etkili olduğu görüşünü akla getirmektedir. Bilginin mutlak ve değişmez olduğu inanc1 eleştirel düşünme olasılığını azaltan bir faktördür. Diğer yandan ebeveynlerin teşvikinin çocukların kararlarında etkili olması ise kültürel yetişme şeklinin eleştirel düşünmeyi etkilemesiyle açıklanabilir. Örneğin, kişinin büyüklerine ya da dini liderlerine çok fazla değer yükleyen toplumlarda "doğrunun" en iyi otorite figürlerinden kazanılan sabit bir varlık olduğuna yönelik epistemik inancın güçlenmesi muhtemeldir (Ormrod, 2018).

Okul öncesi dönemden orta çocukluğa geçişte, eleştirel düşünme açısından yaşanan gelişimsel değişimler Tablo 2'de sunulmuştur.

Tablo 2. Eleştirel Düşünmenin Gelişimi ve Ön Yargılara Karşı Koyma: Gelişimsel Beklentiler (Derman-Sparks'tan akt. Bredekamp, S., 2015: s.197).

\begin{tabular}{ll}
\hline 2 ve 3 yaşlar & Tekrarlanan destekleyici deneyimler yoluyla çeşitli farklılıklarla rahat olmayı öğrenme \\
& Bir şey istediğinde ya da incindiğinde duygularını ifade edebilmeyi öğrenme \\
\hline 4 yaşlar & $\begin{array}{l}\text { Haklı veya haksız davranı̧ imgeleri karşıslaştırarak eleştirel düşünmenin temelini } \\
\text { geliştirmeye başlama }\end{array}$ \\
& Kimlikleri sebebiyle başkalarıyla alay etme ve onları ve reddetmenin acıtıcı olması \\
& Alay ve başkalarının reddi ile başa çıkmak için basit problem çözme ve çatışma \\
\hline
\end{tabular}




\begin{tabular}{ll}
\hline & çözümüyle uğraşma \\
\hline 5 yaşlar & Kalıp yargılar hakkında eleştirel düşünmeye başlama \\
& Haksız ve acıtıcı davranışlar hakkında düşünmeye başlama \\
& Bazı haksız davranış ve yorumları nasıl ele alması konusunda çözüm üretme \\
& Yetişkinlerin yardımıyla, günlük hayatta karşılaştığı ön yargılara karşı koymada diğer \\
& çocuklarla birlikte çalışma (Birlikte arkadaşları için tekerlekli sandalye rampası \\
& yapılmasını talep eden bir dilekçe düzenleme vb.). \\
\hline 6 yaşlar & Gruplar hakkındaki doğru ve yanlış inanışları karşılaştırmaya başlama (“Bazı insanlar \\
& 'Erkekler öğretmen olamaz’ diyor ama Bay Clement olmuş”). \\
& Farklılıklar konusunda soru sorarken saygılı davranma \\
& Problem çözme anlaşmazlıklarının ön yargıları da içermesi \\
\hline 7 ve 8 yaşlar & Kendi fikirlerine nasıl ön yargıların hakim olduğunu düşünme \\
& Yeni oluşan okuma becerilerini cinsiyet, ırk, etnik köken, engellilik ve sınıf \\
& konularında oluşan kalıp ve ön yargıları öğrenmede kullanma \\
& Okul ve yaşadığı topluluğun içindeki ayrımcılık yapılan durumlara değinebilmek için \\
& grup eylemlerine katılma \\
\hline
\end{tabular}

Ergenlik dönemi eleştirel düşünmenin gelişmesinde kritik bir öneme sahiptir. Piaget soyut işlem düşüncesi olarak adlandırdığı bu dönemi somut olandan, burada olmayana ve geleceğe yönelik ilgi sayesinde kurtulma olarak açıklamıştır. Piaget ayrıca ergenlik dönemindeki düşünce dönüşümünü somut ve şimdiki gözlemlerden çıkan önermeler hakkında varsayımlar üretmeyi ve akıl yürütmeyi sağlayan değişim olarak açıklamıştır (Gander \& Gardiner, 2010). Bu dönemde eleştirel düşünmenin ilerleme kaydetmesine olanak tanıyan özelliklerden bazıları; çeşitli alanlardaki bilgi birikiminin artması, bilgi işlemedeki hız, otomatiklik ve kapasite artışı, yeni bilgi kombinasyonları oluşturma becerisinin artması, bilgiyi elde ederken ve kullanırken planlama yapma, alternatifleri dikkate alma, bilişsel izleme gibi strateji ve işlemleri kendiliğinden geniş bir aralıkta uygulamadır. Bunun yanında ergenlik dönemine gelindiğinde okuma ve matematik gibi çocuklukta gerekli becerilerin temeli oluşturulmamışsa eleştirel düşünme becerilerinin yeterince gelişmesinin olanaklı olmadığ 1 belirtilmektedir (Santrock, 2012; Santrock, 2014). Çünkü okuma sırasında zihinsel süreçlerin farkında olmak metindeki içeriğin doğru kavranmasını sağlayarak eleştirel bakış açısını olanaklı kılar. Matematik dersi ise diğer derslere katkıda bulunacak dil ve yöntem olarak ele alındığında çocuklara farklı düşünme stratejileri ve entelektüel beceriler kazandırma anlamında destek olur (Gürkaynak, vd., 2003).

Prefrontal korteksin yapısı ergenlik döneminde önemli değişikliklere uğramaktadır. Ergenler düşünme yapısında orta çocukluk dönemindeki önyargılardan uzaklaşırlar, bu dönemde daha fazla öz-farkında ve öz-yansıtıcı oldukları niteliksel bir değişiklik gözlemlenir. Ergenler çok boyutlu kavramları göz önünde bulundurabilecekleri bir kapasiteye sahip olurlar ve böylece daha stratejik bir şekilde düşünebilirler (Blakemore, \& Choudhury, 2006). Ergenler soyut önermeleri, varsayım olan durumları/olayları anlarlar ve bunlar hakkında mantıklı muhakeme yapabilirler. Orta çocukluk dönemindeki çocuk $A=B$ ve $B=C$, ise $A=C$ mantık yürütmesini yapmak için $\mathrm{A}, \mathrm{B}$ ve $\mathrm{C}$ elementlerini görmeye ihtiyaç duyabilirken ergenlik dönemindeki birey bu problemi sözlü anlatımla çözebilir. Ergenler problem çözerken çocuklukta kullanılan deneme-yanılma yolundan uzaklaşarak bir bilim adamı gibi düşünüp plan geliştirir ve sistemli bir biçimde çözüme ulaşabilirler. $\mathrm{Bu}$ durum onların kuramsaltümdengelimli akıl yürütme yapabildiğini gösterir (Miller, 2017; Santrock, 2012). 
Eleştirel düşünme ergenlik dönemi boyunca gelişme göstermektedir, fakat ergenlerin yalnızca $\% 43$ 'ü bu beceriye sahip olabilmektedir. 11. sınıfa devam eden ergenler bile kendine hizmet eden (self-serving) ön yarg1 gösterebilmektedirler (Gander \& Gardiner, 2010; Santrock, 2012). Ergenlerdeki objektif bakış açısından uzaklaştıran bu ön yargı eleştirel düşünmenin önündeki en büyük engellerden biri olarak görülmektedir (Nosich, 2016). Dumontheil, vd. (2010) zihin teorisinin gelişimini 177 katılımcının olduğu bir araştırmayla incelemişlerdir. Yedi ila 27 yaşları arasındaki katılımcıları beş farklı yaş grubuna ayırmışlardır; Çocuk I (7.3-9.7 yaş); Çocuk II (9.8-11.4); Ergen I (11.5-13.9); Ergen II (14.0-17.7); Yetişkinler (19,1-27,5). Araştırmada tüm gruplara bilgisayar donanımlı görev verilmiştir: Raflarda birtakım objelerin olduğu raf dizisi bulunmaktadır. Bu rafların arkasında bir kişi bulunmaktadır ve bu kişi bazı rafların arkası kapalı olduğu için o nesneleri görememektedir. Rafların arkasındaki kişi objeleri hareket ettirmek için komutlar verir. Örneğin, en üstteki kamyonun sağa kaydırılmasını istediğinde yetişkinlerin bile \%50'si bu görevde hata yapmışlardır. Çünkü rafların arkasındaki kişinin, kapalı olan raflardaki objeleri göremediğini unutmaktadırlar. Aynı uygulama bu sefer rafların arkasında birinin olmadığı, bunun yerine arkasında duvar olan rafların görmezden gelinmesi konusunda kuralların olduğu kontrol grubuna yapılan bir uygulama şeklinde gerçekleştirilmiştir. Araştırmanın sonuçlarına göre, rafın arkasında birinin bulunduğu uygulamada, hata oranı yaş arttıkça azalmıştır. Ancak kişinin değil, kuralların olduğu uygulamada ise ergenliğin sonuna kadar hata oranında azalma olmakla birlikte yetişkinlik döneminde herhangi bir değişme yaşanmamıştır. Bu durum şunu göstermiştir: Kuralları hatırlamakla ve uygulamakla ilgili beceriler ergenlik döneminde gelişir; başkalarının düşüncelerini hesaba katarak hareket etmek ise ergenlik döneminde tamamen gelişmiş değildir. Bu sonuçlar zihin teorisi görevlerinin dört yaşına kadar başarıldığını, zihin teorisi ile yürütücü işlevler arasındaki etkileşimin geç ergenlikte gelişmeye devam ettiğini göstermektedir. Bu açıdan eleştirel düşünmenin yetişkinlikte dahi geliştirilebilen bir beceri olduğu ve eleştirel düşünmenin duyuşsal boyutu akla gelmektedir. Norris ve Ennis (1989)'in eleştirel düşünme eğilimleri arasında yer alan "başkalarının bilgi düzeyine ve duygularına ve entelektüelitesine duyarlı olma” ifadesi Dumontheil, vd.(2010)'nin araştırma sonuçlarıyla ilişkilidir. Dolayısıyla eleştirel düşünmenin ortaya çıkması ve geliştirilmesi için her yaş döneminde desteklenmesi gerekmektedir.

\section{Eleştirel Düşünmenin Desteklenmesi}

Çocukların eleştirel düşünme becerisini geliştirmenin temelinde, üniversite öğrencileri dahil her yaşta öğrenen bireyin farklı kaynaklardaki bilgileri (internet siteleri, ders kitapları, medya raporları vb.) görünen yüzüyle almalarının önüne geçmek bulunmaktadır. Diğer bir deyişle buradaki amaç çocukların okuduklarının ve duyduklarının eleştirel analizini yapmalarını sağlamaktır. Bunun yanı sıra, çocukların eleştirel düşünme becerilerini geliştirmek; okuma, yazma, konuşma ve dinlemeye yönelik iletişimin temel unsurlarını geliştirir; hataları ve ön yargıları keşfetmeye yardımcı olur; özgür düşünceye giden bir yol sunar; bakış açısını değiştirme olanağı sunar; farklı düşünebilme becerisini geliştirir; yeni fikirleri keşfetmenin yolunu açar; bireyin ve grubun potansiyelini ortaya çıkarır; düşüncedeki tıkanıklıkları önler; problemlerde başkalarının göremediği fırsatları görmeyi sağlar (Floera \& Hurjui, 2015).

Eleştirel düşünme becerisi zamanla gelişir ve bu beceri, dil becerileri ve sosyal-duygusal beceriler dahil olmak üzere sayısız öncül beceri üzerine kuruludur (Murphy, vd., 2014). Bu 
nedenle çocukların eleştirel düşünmesini desteklemek yetişkinler açısından kolay bir görev değildir. Ayrıca, eğitim sürecinde eleştirel düşünme becerilerinin desteklenmesi ve geliştirilmesi yetişkinler tarafından çocukların aykırı davranacağı gerekçesiyle kaygıyla karşılanabilir (Heyman, 2008; Kuhn ve Franklin, 2006). Bununla birlikte, eleştirel düşünme karar verme, yaratıcı düşünme ve problem çözme gibi birçok üst düzey düşünmeyle iç içe geçmiş bulunduğundan farklı yollarla desteklenip geliştirilebilir (Lone, 2017; Quinn, 1997). Eleştirel düşünme becerisi desteklenmediğinde çocuklarda bu beceri körelmekte, ilerleyen y1llarda da görülememektedir (Huitt, 1998). Çocuklarda eleştirel düşünme becerisinin gelişimini desteklemek amacıyla farklı program ve yaklaşımların kullanıldığ çeşitli araştırmalar bulunmaktadır (Bono, 1985; Lipman, 1985; MCCall, 2017; Tozduman Yaralı, 2019; Winocur, 1985). Örneğin, Bono (1985) farklı ülkelerde ve kültürlerde yaşayan milyonlarca çocuğun kullandığı, bireylerin nasıl düşüneceğini öğreten 'CoRT düşünme programını'nı geliştirmiştir. Programa yönelik değerlendirme sonuçları, programın, öğrencilerin ortaya konan sorunlara daha geniş bir bakış açısı getirmelerini sağladığını göstermiştir. Lipman (1985) geliştirdiği 'Çocuklar için felsefe (P4C)' programıyla kavramları tartışarak çocukların düşünmeyi düşünme becerisini geliştirmeyi amaçlamıştır. Programın değerlendirme sonuçları çocukların bağlantı kurma ve akıl yürütme becerilerinin geliştiğini ortaya koymuştur. McCall ise 'Felsefi Sorgulama Topluluğu (FST)' adını verdiği yöntemle beş yaş çocuklarının bile akıl yürütme becerilerinin geliştirilebileceğini göstermiştir.

Birçok çocuğun okula başladığında sofistike tarzda düşünmek ya da entelektüel bir çaba harcamak yerine, sorulara tek bir doğru cevap vermeye cesaretlendirildiği pasif öğrenme öyküsü bulunur (Santrock, 2014). Dewey (1933) entelektüel eğitimin asıl probleminin çocuğun dikkat ederken ya da araştırırken az ya da çok olan gündelik merakının ve fikirlerinin dönüştürülmesi sorunu olduğunu belirtmiştir. Çünkü çocuklar en iyi, ilgi duydukları alanlarda deneyimlerken öğrendiklerinden çocukların merak ve ilgi duydukları alanları belirlemek önemlidir. Ayrıca, çocuklara eleştirel düşünmeyi destekleyici bir çevre sunmak gerekmektedir (Şekil 2).

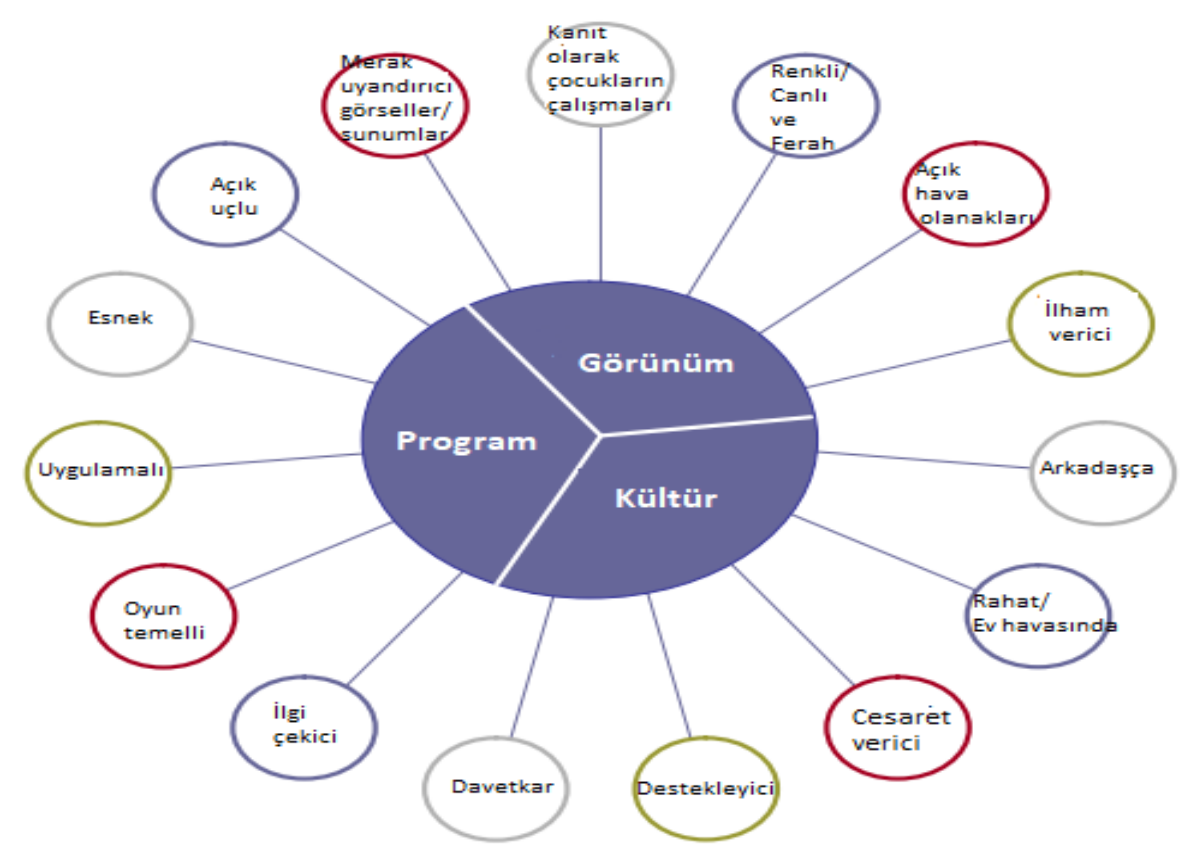




\section{Şekil 2. Düşünmeyi destekleyici çevrenin tamamlayıcı özellikleri. (Walsh, Murphy \& Dunbbar, 2007: s.62).}

Eleştirel düşünme, bireyin görüşlerini özgürce ifade edebildiği güven veren ortamlarda oluşur (Wadsworth, 2015; Williams Howe, 2016). Korkunun egemen olduğu yerde düşünmenin gerçekleştiği beyin bölgesi olan prefrontal korteks devre dışı kalır. Beynin üst kısmı olan prefrontal korteks devre dışı kaldığında planlama, yaratıcı düşünme ve uzun dönemli sonuçları düşünmenin gerçekleşmesi mümkün olmaz (Szalavitz \& Perry, 2017).

Eleştirel düşünmeyi gerçekleştirmek için kullanılan yöntemlerin çoğu bir noktada metabilişe dayanır. Yöntemlerin tümü çocukların düşünme süreçlerini daha açık hale getirmeye çalışır ve çocuklara kendi düşünmeleri üzerinde öz denetim kazandırmaya çalışır (Pithers \& Soden, 2000). Eleştirel düşünmenin öğretiminde kullanılabilecek yöntem ve stratejileri ele alan çeşitli çalışmalar bulunmaktadır (Bonnie, 1994; Gürkaynak, Üstel ve Gülgöz, 2003; Kurfiss, 1988; McCall, 2017). Örneğin, Bonnie (1994), eleştirel düşünme öğretiminde kullanılabilecek yöntemleri incelemiş ve bu konudaki görüşlerini "Eleştirel Düşünme Öğretimi İçin Yöntemler" başlıklı çalışmasında belirtmiştir. Buna göre Bonnie'nin önerileri; bilgiler arasındaki analojileri buldurma, çocukların problem çözerken verilen bilginin gerekliliğini ve uygunluğunu araştırmalarını sağlama, problemlerin farklı çözüm yollarını isteme, çocuklar arasındaki iletişimi ve etkileşimi artırma, çocuklara açı uçlu sorular sorma, soruları yanıtlamaları için onlara yeterince zaman tanıma ve çocuklardan kazandıkları becerileri farklı durumlarda kullanmalarını isteme" şeklinde özetlenebilir. Gürkaynak vd. (2003) ise eleştirel düşünme yaratmak için çeşitli stratejiler belirlemişlerdir; küçük grup ile işbirliği içinde çalışma, örnek olay tartışması, soru hazırlama, yazma ödevleri, diyalog çalışmaları, yaratıcı drama etkinliklerini bu stratejilere örnek göstermişlerdir. Çocukların alışılmadık problem durumlarına maruz bırakılmaları düşünme sürecini destekler ve çocukları derin ve çok boyutlu düşünmeye zorlar. Olaylara başkalarının bakış açısından bakabilmeyi sağlamak ve başkalarının duyguları üzerine konuşmak da çocukların olaylara çok yönlü yaklaşabilmelerini sağlayan unsurlardandır (Williams Howe, 2016).

Okul öncesi çocukların düşünme becerilerini geliştirmek isteyen yetişkinler, bu dönem çocuklarının benmerkezci ve somut düşünce biçimleriyle karşı karşıya kalırlar. Buradaki problem, çocukların kendileri için düşüncelerinin görünmez olmasıdır. Burada yetişkinin görevi, çocuğun düşüncesini kendisi ve diğerleri için görünür hale getirmektir. Düşünceyi görünür hale getirmek ise, onu sorular, konular ve problemler aracılığıyla ortaya çıkarmaktır. Eğitimciler çocukların düşünme üzerine düşünme gelişimlerini desteklemek için düşünce haritaları kullanarak, çocukların resimlerini kullanmak yoluyla belgelendirip düşüncelerini görünür hale getirebilirler. Bunun yanında çocuklar, konuştuklarında, yazdıklarında, çizdiklerinde, inşa ettiklerinde ve dramatize ettiklerinde düşüncelerini görünür hale getirirler. Dolayısıyla belgelendirme (dokümantasyon), çocukların kendi düşünme süreçlerinin farkında olmalarını sağlar (Salmon, 2010). Düşünme üzerine düşünmek, erken çocukluk dönemi için zor görünse de bunu teşvik eden yetişkinler olduğu zaman mümkün olmayan bir durum değildir. Bunun bir yolu, sorularla çocukları düşünmeye teşvik etmektir. Yetişkinler çocuklara ne düşündüklerini sorarak, açık uçlu sorular yönelterek, çocukların dünyayı anlamlandırmalarında veya problem çözmelerinde, hafızalarının ve nesnelerin ötesine geçme firsatı sunarlar (Salmon, 2010). Çocukların düşünme becerilerini geliştirmeleri için karar vermeleri, davranışlarını 
düzenlemeleri, farklı zorluktaki görevlerle karşılaşmaları ve davranışlarının sorumluluğunu almaları gerekmektedir (Epstein, 2013).

Eleştirel düşünmenin geliştirilmesi için yetişkinler tarafindan çocuklara yapılan açıklamaların önemi büyüktür. Yetişkin hem kendi yaptığı, hem çocuktan beklediği davranışın nedenini çocuğa açıklamalıdır. Çocuklardan beklenen davranışın nedeni "Çünkü ben böyle istiyorum" şeklinde bir yaklaşım değil, "O makası öyle tutmamalısın çünkü sivri tarafı elini kesebilir" gibi bir ifadeyle açıklanmalıdır. Çocuk yeni durumlarla karşılaşmadan önce yeni duruma hazırlanmalıdır. Yeni bir aktiviteye başlamadan, yeni bir yer ziyaret edilmeden çocuğa yeni durumun amacına yönelik yapılacak kısa bir açıklama çocukların yeni duruma daha kolay uyum sağlamalarına olanak sağlayacak, öz düzenlemelerini geliştirecek ve eleştirel düşünmelerini destekleyecektir (Galinsky, 2010; McClelland \& Tominey, 2014). Ebeveynler çocuklarının eleştirel/bilimsel düşünmelerine yardımcı olmak için bilim müzesi gibi ortamlarda çocukların kanıtlara odaklanmasına, yeni kanıt toplamalarına, kanıtları yorumlamalarına yardım etmek gibi yollar izleyebilirler (Galinsky, 2010). Yapılan çalışmalar (Chandra, 2008; Gee \& Heyman, 2007) çocukların başkaları/başka şeyler tarafından yanlış yönlendirilebilecekleri konusunda farkındalıklarını arttırmada sosyal deneyimlerin önemini göstermektedir. Çocukları problem durumlarıyla karşı karşıya bırakmak çocukların soyut düşünmelerini destekleyen bir süreç yaratmaktadır (Berk, 2013). Yetişkinlerin çocuklarıyla aldatmacalar, yalan gibi konular üzerinde konuşması eleştirel düşünmenin gelişimi üzerinde etkilidir, ancak bunun doğru yolla yapılması önemlidir. Bir ebeveynin yalan konusunda çocuğuna söyleyeceği "Yalan söylemek kötü insanlar ve cadılar/büyücüler içindir. İyi insanlar ve periler asla yalan söylemezler." gibi katı bir ifade, ebeveynin yalanını yakalayan bir çocuğun güven konusunda kafasının karışmasına ve bazen yalanın başkasının duygularını korumaya hizmet edebileceğini anlamlandırmasına engel olabilir. Burada alternatif, yetişkinin çocukla, yalan söylemenin ahlaki açıdan sorunlu olabileceği sebeplerden bazıları hakkında konuşmasıdır (Heyman, 2008).

Orta çocukluk dönemine geçildiğinde çocukların uzun süreli belleklerinde bir gelişme gözlenir. Bu dönemde çocukların hatırlamalarını kolaylaştıran prova ya da organize etme gibi teknikler kullanılarak çocukların iç bilişsel süreçler hakkında düşünme ve onları yönetme olarak bilinen üstbiliş yetilerine katk1 sağlanabilir. Çocuklar zamanla birilerinin bir şeyleri bilemeyeceği anlayışından, başkalarının kasıtlı ya da kasıtsız olarak aldatıcı olabileceği anlayışına geçerler. Dolayısıyla bilgilerin doğruluğunu değerlendirme becerilerinde ilerlerler. Çocukların bir kitapta veya internette karşılaştığı bilginin doğruluğunu sorgulamasına yardımcı olacak soru olarak çocukların kendilerine "Bu bilginin doğru olduğunu nasıl anlayabilirsin?" sorusunu yönlendirmeleri sağlanabilir. Ayrıca çocuğu, bir kişinin söylediği yalanın ardındaki sebeplere bakmaya cesaretlendirmek gerekir. Özellikle orta çocukluk döneminde eleştirel düşünmenin geliştirilmesinde reklamlardan yararlanılabilir. "Bu reklam neyi satmaya çalışıyor? Neden reklam şirketi ürünü satmak için bu yolu seçmiş olabilir?" gibi sorular çocuklarla reklam hakkında konuşulurken kullanılabilir (Galinsky, 2010; Ormrod, 2018). Ayrıca, günlük hayatta karşılaş1lan sorunların çözümünde eleştirel düşünme becerilerinden yararlanan bir problem çözme süreci kullanmak faydalı olabilir (Tablo 2) 
Tablo 3. Problem çözme sürecine yönelik uygulama basamakları (Galinsky, 2010: s.201)

\begin{tabular}{|c|c|}
\hline 1.İkilemi, problemi ya da sorunu tanımlayın. & $\begin{array}{l}\mathrm{Bu} \text { aşamada soru sormak gerekir: "Şimdi } \\
\text { neredeyim? Olmak istediğim yer neresi? İstediğim } \\
\text { noktaya varmamı sağlayacak şeyler neler olabilir?" }\end{array}$ \\
\hline 2. Hedefi belirleyin. & $\begin{array}{l}\text { Problem çözme hedef odaklıdır; o yüzden bir } \\
\text { hedef belirlenir. }\end{array}$ \\
\hline 3.Alternatif çözümler bulun. & $\begin{array}{l}\text { Esnek düşünerek var olanların dışında yeni } \\
\text { çözümler bulmaya çalışılır. }\end{array}$ \\
\hline $\begin{array}{l}\text { 4.Bu alternatif çözümlerin } \text { nasıl işe } \\
\text { yarayabileceğini düşünün. }\end{array}$ & $\begin{array}{l}\text { Çözüm başkalarının bakış açısından görülmeli, } \\
\text { objektif olunmaya çalışılmalıdır. }\end{array}$ \\
\hline 5.Denemek için bir çözüm seçin. & $\mathrm{Bu}$ aşama yansıtıcı ve eleştirel düşünme gerektirir. \\
\hline $\begin{array}{l}\text { 6. Sonucu değerlendirin ve eğer çözüm işe } \\
\text { yaramıyorsa başka bir şey deneyin. }\end{array}$ & $\begin{array}{l}\text { Yapılan plan hedeflenen sonuca ulaştırmıyorsa } \\
\text { planı değiştirmeye yenilemeye karar verilir. }\end{array}$ \\
\hline
\end{tabular}

Tablo 3’te belirten problem çözme sürecini kullanmak çocukların yürütücü işlevlerini kullanarak eleştirel düşünme becerisini destekler. Yürütücü işlevler; özdenetim, işleyen bellek ve bilişsel esneklik boyutlarından oluşur. Tablo 3'te yer alan problem çözme sürecinde kullanılan basamaklar çocukların odaklanmasına (özdenetim), hedefe giden yolda farklı alternatifleri denemeye (bilişsel esneklik), ve yapılan işle ilgili bilgileri kısa süre içinde unutmamasına (işleyen bellek) yardımcı olur (Aamodt ve Wang, 2018; Galinsky, 2010).

Sternberg (1985) ergenlik döneminde eleştirel düşünme öğretilirken soyut akıl yürütme görevlerine odaklanıldığını, ancak günlük yaşamın gerektirdiği eleştirel düşünme becerilerinin geri planda kaldığını belirtmektedir. Oysaki günlük yaşamda ergenlere gerekli olan beceriler arasında; var olan problemin farkına varma, problemi ifade edebilme, birden fazla yanıtı olan problemi ele alma, kişisel konularda karar verme, bilgi elde etme ve uzun süreli problemlere uzun süreli yaklaşımlar geliştirme becerileri yer almaktadır (Sternberg, 1985). Ergenleri eleştirel düşünmeye yöneltmenin bir yolu, farklı bakış açılarına sahip olmayı olanaklı kılan tartışmalı konular sunan makaleler vermektir. Çocuklar konuyu derinlemesine araştırmaya ve sorunu gidermeye yönelik müzakere ve savunma yapmaya çalışırken eleştirel düşünme desteklenir (Kuhn ve Franklin, 2006; Murphy, vd, 2014). Hatta, bazen kendilerinin savunmadıkları/muhalif oldukları konularda taraf olarak tartışmaları sağlanabilir (Ormrod, 2018). Bu onarın 'açık fikirlilik' ve 'esneklik' gibi farklı özelliklerini geliştirecektir. Ergenlik döneminde eleştirel düşünmeyi teşvik eden bir öğrenme ortamında, eleştirel analizler, tartışma grupları, dramatizasyon, kritik olay, senaryo oluşturma, sokratik sorgulama, yaratıcı görselleştirme, dinleme grupları, günlük yazma, karikatürler kullanılabilir (Jones \& Safrit,1992). Amerika Birleşik Devletleri'ndeki ve gelişmemiş ülkelerdeki ergenler, ileri düzeydeki akıl yürütme becerilerinde gelişmiş ülkelerin gerisinde kalmaktadırlar. Bunun temel nedeni olarak gerekçeli düşünme yerine, ezberci öğrenmeye yapılan vurgunun, çocukların bilişsel potansiyel seviyeye ulaşmasını engellemesi gösterilmektedir (Chapman, Gamino, \& Mudar, 2012; Gürkaynak, vd., 2003). Sonuç olarak, tüm gelişim dönemleri için eleştirel düşünmede bilişsel becerilerin ve duyuşsal özellikleri içeren eğilimlerin bir arada ele alınması gerekmektedir. Değerlendiren, analiz eden, yorumlayan bireyin bu bilişsel becerileri etkili kullanabilmesi için gerekli olan şey 
bu becerileri kullanabilmesini sağlayan motivasyon, merak, esneklik gibi duyuşsal becerilerdir (Facione, 1990; Wadsworth, 2015).

\section{Sonuç}

Üst düzey düşünme becerisi olarak eleştirel düşünme, bilginin doğruluğunu ve güvenirliğini değerlendirmedir. Bilgi akışının yoğun olduğu günümüzde hem okul öncesi, hem orta çocukluk hem de ergenlik dönemindeki bir çocuk için eleştirel düşünme, aldatmacalardan korunma ve doğru bilgiye ulaşmada bir gereklilik haline gelmiştir. Eleştirel düşünme bireyin gelişimsel sürecinde edinilen birtakım beceriler sonucunda zamanla ortaya çıkar. Zihin kuramı ve yürütücü işlevlere yönelik kazanımlar bu becerilerden bazılarıdır. Bebeklikte amaçlı davranmaya başlama, niyetleri algılama; okul öncesinde zihin kuramı becerilerinin gelişimi, yürütücü işlevlere ait kazanımlar; orta çocuklukta zihinsel stratejilerin kazanımı ve ergenlik döneminde edinilen tümdengelimli akıl yürütme, hipotetik düşünme eleştirel düşünme becerisinin gelişmesine katkıda bulunur. Gelişimsel anlamda eleştirel düşünme açısından bu süreci anlamak yetişkinlerin çocuklardan beklentisini şekillendirmeye yardımcı olacak ve çocukların eleştirel düşünme becerilerini geliştirmek için destekleme konusunda onlara yol gösterecektir. Okul öncesinden ergenliğe çeşitli gelişim dönemlerine yönelik farklı yöntem ve tekniğin çocukların eleştirel düşünme becerilerine etkisinin sınandığı araştırmalar yapılması önerilebilir. Ayrıca, eleştirel düşünmenin genel olarak bilişsel ve duyuşsal boyut olarak ele alındığı görüldüğünden, daha güncel olan ve bazı araştırmacılar tarafından bir boyut olarak değerlendirilen ideolojik ve ontolojik inançlar konusunda farklı yaş gruplarıyla kapsamlı araştırmalar yürütülmesi önerilebilir. 


\section{Kaynakça}

Aamodt, S. \& Wang, S. (2018). Çocuğunuzun beyine hoş geldiniz: Doğum öncesi dönemden üniversite çağına kadar beyin gelişimi. (Çev. Cem Duran). İstanbul: İndigo Kitap.

Altıntaş, M. (2014). Çocuklar için zihin kuramı test bataryası'nın 4-5 yaş Türk çocuklarına uyarlanması, geçerlik güvenirlik çalışması. Yayınlanmamış yüksek lisans tezi, Haliç Üniveristesi.

Amsterlaw, J. (2006). Children's beliefs about everyday reasoning. Child Development, 77(2), 443-464.

Astington, J. W., Pelletier, J., \& Homer, B. (2002). Theory of mind and epistemological development: The relation between children's second-order false-belief understanding and their ability to reason about evidence. New Ideas in Psychology, 20(2-3), 131-144.

Avc1, N. (2007). Gelişimde 0-3 yaş. "Yaşama merhaba" İstanbul: Morpa.

Başarer, D. (2017). Bir düşünme türü olarak mantıksal düşünme. Akademik Sosyal Araştırmalar Dergisi, 5(41), 433-442.

Bee, H., \& Boyd, D. (2009). Çocuk gelişim psikolojisi. (Çev. Orhan Gündüz). İstanbul: Kaknüs Yayınları.

Berk, L. E. (2013). Çocuk gelişimi (B. Onur. ve A. Dönmez, Çev.). Ankara: İmge.

Blakemore, S. J., \& Choudhury, S. (2006). Development of the adolescent brain: implications for executive function and social cognition. Journal of Child Psychology and Psychiatry, 47(3-4), 296312.

Bonnie, P. (1994). Srtategies for teaching critical thinking. Washington DC: Clearinghouse on Assessment and Evaluation.

Bono, E. (1985). The CoRT thinkinf program. (s. 205-211). Developing Minds: A Resource Book for Teaching Thinking. Ed. Costa, A. L. Association for Supervision and Curriculum Development, 225 N. Washington St., Alexandria, VA 22314, 1985.

Bredekamp, S. (2015). Erken çocukluk eğitiminde etkili uygulamalar. Z. İnan \& T. İnan (Ed.), Kültürel ve dilsel farklılıkları benimseme (Z. Öztürk, Çev.) içinde (s. 170-203). Ankara: Nobel.

Bruning, R., Schraw, G., \& Ronning, G. G. (1995). Cognitive psychology and instruction. New Jersey: Prentice-Hall Inc.

Carlson, S. M., Davis, A. C. \& Leach, J. G. (2005). Less is more: Executive function and symbolic representation in preschool children. Psychological Science, 16(8), 609-616.

Carlson, S. M., Mandell, D. J., \& Williams, L. (2004). Executive function and theory of mind: stability and prediction from ages 2 to 3. Developmental Psychology, 40(6), 1105-1022.

Chandra, J. S. (2008). A Vygotskykian perspective on promoting critical thinking in young children through mother-child interaction. Unpublished doctoral dissertation, Murdoch Üniversitesi, Perth.

Chapman, S. B., Gamino, J. F., \& Mudar, R. A. (2012). Higher order strategic gist reasoning in adolescence. The adolescent brain: Learning, reasoning, and decision making , (pp. 123-151). Washington, DC, US: American Psychological Association.

Cheung, C. K., Rudowicz, E., Kwan, A. S., \& Yue, X. D. (2002). Assessing university students' general and specific critical thinking. College Student Journal, 36(4), 504-526.

Dağlığlu, H. E., \& Çakır, F. (2010). Erken çocukluk döneminde düşünme becerilerinden planlama ve derin düşünmenin geliştirilmesi. Eğitim ve Bilim, 32(144), 28-35. 
Daniel, M., \& Auriac, M. (2011). Philosopy, critical thinking and philolophy for children. Educational Philosophy and Theory, 43(5), 415-435.

Davis-Seaver, J., Smith, T. \& Leflore, D. (2003). Constructivism: A path to critical thinking in early childhood. International Journal of Scholarly Academic Intellectual Diversity, 7(1), 1-7.

Dean, D., \& Kuhn, D. (2003). Metacognition and critical thinking. EDRS Price MFO1 /PCO1 Plus Postage.

DeLoache, J. S. \& Pickard, M. B. (2008). "Transfer Between Picture Books and the Real World," Cognition and Development, 9(1), 46-66.

Demirel, Ö. (1999). Kuramdan uygulamaya eğitimde program geliştirme. Ankara: Pegem

Dewey, J. (1933). How we think: A restatement of the relation of reflective thinking to the educative process. Boston: MA: Heath.

Dumontheil, I., Apperly, I. A., \& Blakemore, S. J. (2010). Online usage of theory of mind continues to develop in late adolescence. Developmental Science, 13(2), 331-338.

Eisbach, A. O. D. (2004). Children's developing awareness of diversity in people's trains of thought. Child Development, 75(6), 1694-1707.

Ennis, R. H. (1985). A logical basis for measuring critical thinking skills. Educational Leadership, 43(2), 44-48.

Epstein, A. S. (2013). Helping Preschoolers Build Their Thinking Skills. Teaching Young Children, 7(1), 20-23.

Estes, D., Wellman, H., \& Woolley, J. (1989). Children's understanding of mental phenomena. In H. Reese (Ed.), Advances in child development and behavior (pp. 41-87). New York: Academic Press.

Facione, P.A. (1984). Toward a theory of critical thinking. Liberal Education, 70, 253-261.

Facione, P. A. (1990). Critical thinking: A statement of expert consensus for purposes of educational assesment and instruction-executive summary-The Delphi Report. www. researchgate.net sayfasından erişilmiş̧ir.

Flavell, J. H. (1999). Cognitive development: Children's knowledge about the mind. Annual Review of Psychology, 50(1), 21-45.

Flavell, J. H., \& Miller, P. H. (1998). Social cognition. In W. Damon (Ed.), Handbook of child psychology: Vol. 2. Cognition, perception, and language (pp. 851-898). Hoboken, NJ, US: John Wiley \& Sons Inc.

Flavell, J. H., Green, F. L., Flavell, E. R., Harris, P. L., \& Astington, J. W. (1995). Young children's knowledge about thinking. Monographs of The Society for Researchi in Child Development, 60(1), 1113 .

Florea, N. M., \& Hurjui, E. (2015). Critical thinking in elementary school children. Procedia-Social and Behavioral Sciences, 180, 565-572.

Galinsky, E. (2010). Geliş̧en zihin: Her çocuğun ihtiyaç duyduğu yedi temel yaşam becerisi. (Çev. Kevser T. Yaralı ve Elifcan Cesur) Ankara: Nobel.

Gander, M. J. \& Gardiner, H. W. (2010). Çocuk ve ergen gelişimi. (Yay. Haz. Bekir Onur). Ankara: İmge.

Gee, C. L., \& Heyman, G. D. (2007). Children's evaluation of other people's self-descriptions. Social Development, 16(4), 800-818. 
Gürkaynak, İ., Üstel, F., \& Gülgöz, S. (2003). Eleştirel düşünme. İstanbul: Eğitim Reformu Girişimi.

Halpern, D. F. (1998). Teaching critical thinking for transfer across domains: dispositions, skills structure training, and metacognitive monitoring. American Psychologist, 53, 449-445.

Hamlin, J. K., Wynn, K., \& Bloom, P. (2007). Social evaluation by preverbal infants. Nature, 450, 557560.

Heyman, G. D. (2008). Children's critical thinking when learning from others. Current Directions in Psychological Science, 17(5), 344-347.

Heyman, G.D., Fu, G.,\&Lee, K. (2007). Evaluating claims people make about themselves: The development of skepticism. Child Development, 78, 367-375.

Hoicka, E., Butcher, J., Malla, F., \& Harris, P. L. (2017). Humor and preschoolers' trust: Sensitivity to changing intentions. Journal of Experimental Child Psychology, 154, 113-130.

Huitt, W. (1998). Critical thinking: An overwiew. Educational Psychology Interactive, 3, http://www. edpsycinteractive.org/topics/cognition/critthnk. Retrieved on October 11.2018.

Inhelder, B., \& Piaget, J. (1958). An essay on the construction of formal operational structures. The growth of logical thinking: From childhood to adolescence (A. Parsons \& S. Milgram, Trans.). New York, NY, US.

Jones, J. O., \& Safrit, R. D. (1992). Critical Thinking: Enhancing Adolescent Decision Making. Journal of Home Economics, 84(3), 4-7.

Kuhn, D. (1999). A developmental model of critical thinking. Educational Researcher, 28(2), 16-26.

Kuhn, D. (2000). Theory of mind, metacognition, and reasoning: A life-span perspective. Children's reasoning and the mind, In P. Mitchell \& K. J. Riggs (Eds.), 301-326. U.K.: Psychology Press.

Kurnaz, A. (2013). Eleştirel düşünme ögrretimi etkinlikleri planlama-uygulama ve değerlendirme. İstanbul: Eğitim Kitabevi.

Lee, K., \& Cameron, C.A. (2000). Extracting truthful information from lies: Emergence of the expression representation distinction. Merrill-Palmer Quarterly, 46, 1-20.

León, J. M. (2015). A baseline study of strategies to promote critical thinking in the preschool classroom (Un Estudio de Base sobre Estrategias para la Promoción de Pensamiento Critico en las Aulas de Preescolar). GIST Education And Learning Research Journal, 10, 113-127.

Lewis, A., \& Smith, D. (1993). Defining higher order thinking. Theory Into Practice, 32(3), 131- 137.

Lipman, M. (1985). Philosophy for children. (s. 214-216). Developing Minds: A Resource Book for Teaching Thinking. Ed. Costa, A. L. Association for Supervision and Curriculum Development, 225 N. Washington St., Alexandria, VA 22314, 1985.

Lone, J. M. (2017). Filozof çocuk. İstanbul: Solo Unitas.

Louca, E. P. (2008). Metacognition and Theory of Mind. by Cambridge Scholars Publishing.

Lutz, D.J., \& Keil, F.C. (2002). Early understanding of the division of cognitive labor. Child Development, 73, 1073-1084.

Madi, B. (2014). Öğrenme beyinde nasıl oluşur? Ankara: Efil Yayınevi.

Matthews, G. B. (2000). Çocukluk felsefesi. İstanbul: Gendaş Kültür.

McCall, C. C. (2017). Düşünmeyi dönüştürmek. (Çev. Kurtul Gülenç ve Nihal P. Boyacı). Ankara: Nobel Akademik Yayıncılık. 
McClelland, M. M., \& Tominey, S. L. (2014). The Development of Self-Regulation and Executive Function in Young Children. Zero to Three, 1-9.

McKnown, K. (1997). Fostering critical thinking. USA: A Research Paper to Ait Command and Staff Collage

Miller, P. H. (2017). Gelişim psikolojisi kuramları. (Yay. Haz. B. Onur). Ankara: İmge.

Miller, S. A., Hardin, C. A., \& Montgomery, D. E. (2003). Young children's understanding of the conditions for knowledge acquisition. Journal of Cognition and Development, 4(3), 325-356.

Mills, C.M., \& Keil, F.C. (2005). The development of cynicism. Psychological Science, 16, 385-390.

Moses, L.J., \& Baldwin, D.A. (2005). What can the study of cognitive development reveal about children's ability to appreciate and cope with advertising? Journal of Public Policy and Marketing, 24, 186-201.

Moshman, D. (1998). Cognitive development beyond childhood: Constraints on cognitive development and learning. In W. Damon (Series Ed.), D. Kuhn, \& R. Siegler (Vol. Eds.), Handbook of child psychology: Vol. 2. Cognition, language, and perception (5th ed., pp. 947-978). New York: Wiley.

Murphy, P. K., Rowe, M. L., Ramani, G., \& Silverman, R. (2014). Promoting critical-analytic thinking in children and adolescents at home and in school. Educational Psychology Review, 26(4), 561-578.

Norris, P. S., \& Ennis, R. (1989). Evaluating critical thinking. Pacific Grove, CA: Critical Thinking Press and Software.

Nosich, G. M. (2016). Eleştirel düşünme ve disiplinler arası eleştirel düşünme rehberi. (Çev. B. Aybek), Ankara: Anı

Olson, D., \& Astington, J. (1993). Thinking about thinking: Learning how to take statements and hold beliefs. Educational Psychologist. 28(1), 7-23.

Ormrod, J. E. (2018). Öğrenme psikolojisi. (Çev. Ed. Mustafa Baloğlu). Ankara: Nobel.

Özsoy, G. (2008). Üstbiliş. Türk Eğitim Bilimleri Dergisi, 6(4), 713-740.

Paul, R., Binker, A. J. A., Martin, D., Vetrano, C., \& Kreklau, H. (1995). Critical Thinking Handbook 6th-9th Grades: A guide for remodeling lesson plans in Language Arts. Social Studies \& Science. Santa Rosa, CA: Foundation for Critical Thinking.

Paul, R. (1990). Critical thinking. Rohnert Park, CA: Center for Critical Thinking and Moral Critique Sonoma State University.

Paul, R., \& Elder, L. (2002). Critical thinking: Tools for taking charge of your professional and personal life. NY : Prentice Hall.

Piaget, J. (1952). The origins of intelligence in children. New York: International Universities Press.

Pithers, R. T., \& Soden, R. (2000). Critical thinking in education: A review. Educational Research, 42(3), 237-249.

Quinn, V. (1997). Critical thinking in young minds. London: David Fulton.

Rogers, E. M. (2003). Diffusion of innovation (5th ed.). New York: Free Press.

Rosengren, K. S., Kalish, C. W., Hickling, A. K., \& Gelman, S. A. (1994). Exploring the relation between preschool children's magical beliefs and causal thinking. British Journal of Developmental Psychology, 12(1), 69-82.

Salmon, A. K. (2010). Tools to enhances young children'sthinking. Young Children. 2(3) 26-32. 
Santrock, J. W. (2012). Yaşam boyu gelişim. (Çev Ed. Galip Yüksel) Ankara: Nobel.

Santrock, J. W. (2014). Ergenlik. (Çev. Ed. Diğdem M. Siyez). Ankara: Nobel.

Saxe, R. R., Whitfield-Gabrieli, S., Scholz, J., \& Pelphrey, K. A. (2009). Brain regions for perceiving and reasoning about other people in school-aged children. Child Development, 80(4), 1197-1209.

Sternberg, R. J. (1985). Teaching critical thinking. Part 2: Possible solutions. Phi Delta Kappan, 67(4), 277-280.

Szalavirtz, M. \& Perrry, B. D. (2017). Sevmek için doğarız. İstanbul: Kuraldış1.

Tozduman Yaralı, K. (2019). Okul öncesi çocuklarm eleştirel düşünme becerilerine öyküleştirme yöntemine dayah eğitim programının etkisi. Doktora tezi, Gazi Üniversitesi, Ankara.

Trawick-Smith, J. (2018). Erken çocukluk döneminde gelişsim (Çok kültürlü bir baklş açısı). (Çev Ed. Berrin Akman). Ankara: Nobel.

Wadsworth, B. J. (2015). Piaget'in duyuşsal ve bilişsel gelişim kuramı. (Çev Ed. Ziya Selçuk). Ankara:Pegem Akademi

Walsh, G. Murphy, P., \& Dunbar, C. (2007). Thinking skills in the early years: A guide for practitioners.Written in collaboration with the early years enriched curriculum evaluation Project team. Retrieved on October 25, 2018.

Watson, G. \& Glaser, E. M. (1980). Watson-Glaser Critical Thinking Appraisal. Cleveland, OH: Psychological Corporation

Wellman, H., \& Gelman, S. (1998). Knowledge acquisition in foundational domains. In W. Damon (Series Ed.), D. Kuhn, \& R. Siegler (Vol. Eds.), Handbook of child psychology: Vol. 2. Cognition, language, and perception (5th ed., pp. 523-574). New York:Wiley.

Whitebread, D., Anderson, H., Coltman, P., Page, C. PinoPasternak, D., \& Metha, S. (2004). Metacognition in 3-5 year olds.: Evidence form a naturalistic study in British early years educational settings. Paper Presented at First Meeting of TheEarly Metacognition Special Interst Group, Amsterdam.

Williams Howe, C. (2016). How to raise critical thinkers in a world that desperately needs them. http://www.parent.com. Retrieved on October 25, 2018.

Winocur, S. L. (1985). Proje Impact. (s. 212-213). Developing Minds: A Resource Book for Teaching Thinking. Ed. Costa, A. L. Association for Supervision and Curriculum Development, 225 N. Washington St., Alexandria, VA 22314, 1985.

Wood, D. (2003). Çocuklarda düşünme ve öğrenme. İstanbul: Doruk.

Zelazo, P., \& Frye, D. (1998). Cognitive complexity and control: II. The development of executive function in childhood. Current Directions in Psychological Science, 7, 121-125 


\section{Extended Abstract}

\section{Introduction}

Critical thinking is one of the higher order thinking skills. It is a valid and reliable quest of information for individuals to direct their decisions, beliefs and behaviors (Galinsky, 2010). All individuals, especially children need to have a skill of assessing the information in a critical way in order to discern which rapidly-reached information is reliable. Critical thinking is a necessity for other thinking skills such as creative thinking, problem solving, and decision making (Kurnaz, 2013). The researchers have established a relationship between critical thinking and metacognition. Described as a cognition about cognition; metacognition has been addressed by Kuhn (2000) and the theory of mind has been considered as the center of metacognition. While cognition requires perceiving, understanding and remembering metacognition requires the thoughts of an individual about her/his own perceiving, understanding and remembering. Kuhn (1999) states that there are three conditions to realize critical thinking as; metacognition knowledge, metacognition strategies and epistemological knowledge. Metacognition develops with age in general; however, it is indicated that the effect of teaching is greater than the effect of maturation in acquiring metacognition skills (Louca, 2008; Özsoy, 2008).

\section{Critical Thinking from Infancy to Adolescence: Developmental Changes in Critical Thinking}

Mental capacity that is necessary for higher order thinking skills develops within a process that continues lifelong. Also the bases of critical thinking are laid during infancy and developed throughout life. It is not easy to question infants about their thoughts; however, their behaviors allow us to estimate their thoughts. When infants are 18-24 months old, they may react with inventions including thoughts and generate solutions to problems via envisioning. This stage is called as "beginning of thought" or "projected thought" (Berk, 2013; Miller, 2017). According to Piaget, children between the ages of two and four are in the symbolic function stage and they can mentally express an object which is not there at that moment. In this stage, the language development accelerates. Thought and speaking are egocentric. In the intuitive thought sub stage which covers the ages of four and seven, on the other hand, children start reasoning and asking questions frequently. A decrease is observed in egocentrism. Children are able to express their opinions with proper and long sentences (Bee \& Boyd, 2009; Santrock, 2014). Children aged between three and five begin to think that claims are someone's way of expressing their beliefs (Olson and Astington, 1993). This forms a basis for critical thinking and is a critical sign in the development of metacognition. When children obtain this insight, they develop the ability of representing mental states; for example, they can distinguish thinking about a dog actually from perceiving someone (Estes, Wellman \& Woolley, 1989). In addition, they begin to use mental state concepts like desire and intention as a means for explaining their and other people's behaviors (Berk, 2013). Children in the preschool period begin to understand the possibility of deceiving. They learn that appearance and reality may sometimes differentiate and people may have wrong beliefs. Children's beliefs toward mental activities which are called as the theory of mind throughout middle childhood become more detailed and comprehensive. Because children in this period are able to reflect their own experiences, it is possible to observe a better progress in their thinking skills such as critical thinking and problem solving. In middle childhood, children become more conscious in terms of mental strategies. They realize that a mental 
activity/cognitive performance is affected by multiple factors (such as age, motivation, difficulty level of a task and use of strategies) and begin to use these factors together in order to make their understanding more efficient. Adolescence is critical in the development of critical thinking. Piaget calls this period an abstract operational thought and explains it as a salvation from the concrete by means of what not existing here and the interest in the future. Piaget also explains the thought transformation in adolescence as a change which enables making assumptions and reasoning on resolutions rising from concrete and present observations (Gander \& Gardiner, 2010). Some of the features that allow critical thinking to progress in this period are as follows; increase of accumulation of knowledge in various areas, acceleration in data processing, increase of automatism and capacity, increase of the skills of forming new knowledge combinations, obtaining and using the knowledge according to a plan, considering alternatives and applying automatically strategies and operations such as cognitive monitoring in an wide range. Critical thinking keeps developing throughout adolescence, but only $43 \%$ of adolescents are able to acquire this skill (Santrock, 2012).

\section{Support of Critical Thinking}

Critical thinking develops in confidential environments where an individual can express her/his opinions freely (Williams Howe, 2016). Adults who want to develop thinking skills of preschool children encounter with their egocentric and concrete thinking styles. The problem here is that to children, their thoughts are invisible. At this point, the role of a trainer is to make the child's thoughts visible for both herself/himself and the others. On the other hand, making a thought visible is possible through revealing it via questions, subjects and problems. Trainers can make children's thoughts visible and document them through using thought maps and children's paintings in order to support their thinking development on thinking. In addition, children make their thoughts visible when they speak, write, draw, build and dramatize. Thus, documentation enables children to be aware of their own thinking processes (Salmon, 2010).

When children reach middle childhood, a development is observed in their long-term memory. Using techniques in this period such as rehearsal or organization which enable children to remember may contribute to their metacognition competence, which is known as thinking about and managing internal cognitive processes. Children dispense with thinking that someone may not know some things and begin to think that others may be deceptive either deliberately or in deliberately in the course of time. Thus, they progress in their skills of assessing the accuracy of information. Enabling children to ask themselves, "How can you understand whether this information is accurate?" may help them examine the accuracy of information that they encounter in a book or on the internet. In addition, it is necessary to encourage the child to examine the reasons underlying a lie that a person tells (Galinsky, 2010). In order to motivate adolescents to critical thinking, articles presenting disputable subjects with multiple aspects can be given. Critical thinking is supported as children try to investigate the subject profoundly and solve the problem in their speeches and debates (Kuhn and Franklin, 2006; Murphy et al., 2014). 